\title{
Hydrogen applications and research activities in its production routes through catalytic hydrocarbon conversion
}

DOI 10.1515/revce-2016-0040

Received September 16, 2016; accepted December 23, 2016

Abstract: The statistical information on the share of hydrogen sector-wise consumption indicates that $95 \%$ of the total consumption is utilized in ammonia synthesis, petroleum refining processes and methanol production. We discuss how hydrogen is used in these processes and in several smaller-scale manufacturing industries. We also present the trend of hydrogen used as fuel, and as an energy carrier in fuel cells for generating electricity, powering hydrogen vehicles, as well as in aerospace applications. Natural gas caters for approximately half of the total hydrogen production resources. Therefore, the scope is emphasized on relatively recent developments in research activities related to the conventional catalytic hydrocarbon processing technologies for the production of hydrogen derived from natural gas (methane), which are steam methane reforming, partial oxidation of methane and autothermal reforming. Hydrocarbon decomposition is included due to its potential to be industrialized in the future, and its benefits of producing clean hydrogen without emissions of greenhouse gases and generating carbon nanofibers or nanotubes as by-products that have the potential in various emerging applications. Attention is given to the efforts toward achieving hydrocarbon conversion improvements, energy savings through thermally efficient operation and reduced operational costs through minimization or elimination of coke formation in the catalytic processes.

Keywords: autothermal reforming; hydrogen applications; hydrogen production; methane decomposition; partial oxidation; steam methane reforming.

\footnotetext{
*Corresponding author: Matthew James Watson, Department of Chemical and Process Engineering, College of Engineering, University of Canterbury, Private Bag 4800, Christchurch 8140, New Zealand, e-mail: matthew.watson@canterbury.ac.nz Luqmanulhakim Baharudin: Department of Chemical and Process Engineering, College of Engineering, University of Canterbury, Christchurch 8140, New Zealand
}

\section{Introduction}

Hydrogen has been used mainly in petroleum refining processes such as desulfurization and cracking of oil, as an essential reactant, as well as in chemical industries as a raw material or syngas for synthesis of key chemicals; among others include methanol, dimethyl ether and ammonia (Chen et al. 2010). In addition, CO from the syngas (mixture of hydrogen and $\mathrm{CO}$ ) is further chlorinated to produce phosgene, which is used as a starting point in the manufacturing other end-user chemicals including plastics, pesticides, dyes and herbicides (Chilcott 2007).

Based on historical data (Figure 1), it was indicated that just less than $50 \%$ of the total consumption of hydrogen in the USA in 1974 was in petroleum refining, followed by slightly above $35 \%$ in ammonia synthesis and up to $10 \%$ in methanol synthesis. This means that close to $95 \%$ of the total hydrogen consumption was made up by industrial-scale applications. The remaining pie was grouped together in miscellaneous uses (Dahiya and Chand 1987).

In 1975, a projection of hydrogen utilization for the year 2000 was made, where the industrial-scale applications would no longer be the leading consumers. Hydrogen consumption in the synthesis of chemicals (ammonia, methanol, etc.) and petroleum refining processes would only account for slightly above $40 \%$ of the total projected utilization. This is even less than half of the actual industrial-scale utilization in 1974, even though the total consumption was estimated to increase 22 -fold from $1.00 \times 10^{5}$ $\mathrm{Btu}$ (the unit was given as hydrogen energy in the statistical data).

The remaining hydrogen consumption was projected to be taken up by hydrogen used as synthetic fuels and energy, as well as for transportation and other energyrelated uses. It was anticipated that hydrogen would be heavily utilized as a fuel in various industrial, commercial and domestic applications, as well as in the storage for use in automobiles and electrical power generation (Dahiya and Chand 1987).

Interestingly, after more than three decades, the global share of hydrogen consumption data in the 2000s (Ashik et al. 2015) showed that the utilization has still 


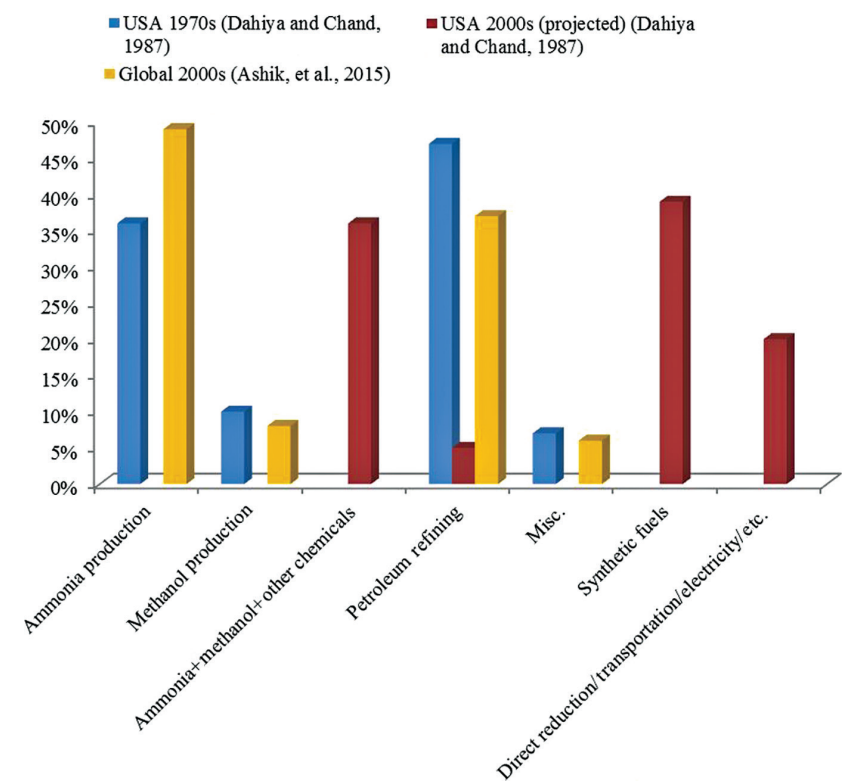

Figure 1: Share of hydrogen sector-wise consumption.

been dominated by industrial-scale applications. As presented in Figure 1, in comparison with the US hydrogen consumption data (1974), the only difference here is a swap of positions between ammonia production and petroleum refinery processes, but a similar trend is seen on hydrogen utilization in methanol production and miscellaneous uses.

Similarly in China, more than $95 \%$ of the total hydrogen consumption in the 2000s was utilized by the same top three large-scale sectors (i.e. synthesis of ammonia and methanol, and petroleum refining). Around $75 \%$ of the hydrogen was consumed for ammonia synthesis, at an ammonia annual production growth rate of $9 \%$. Methanol output was also grown tremendously on yearly basis at the rate of as high as $39 \%$, which increased accordingly the consumption of hydrogen in China. The increasing trend in the annual growth rate was also seen in fuel oil consumption at $7 \%$, which subsequently led to a higher import volume of crude oil of high sulfur content, and hence resulted in an increase in the amount of hydrogen utilized in the petroleum refinery processes for the purpose of hydrofining and hydrocracking. Between 2000 and 2007, the total consumption of hydrogen in China increased at an annual growth rate of above $9 \%$. The consumption increased by around 5 million tonnes in 2007 from 7 million tonnes in 2000 (Hewu et al. 2013).

The constituents of hydrogen utilization in the category of miscellaneous uses were not identified in the statistics. Based on the general applications of hydrogen presented in various literature, the miscellaneous uses could include other industries such as electronics and semiconductors (Hewu et al. 2013), plastics, steel, ferrous and nonferrous metallurgy, food and edible oils processing (Dahiya and Chand 1987, Hewu et al. 2013) through a catalytic hydrogenation process, float glass and fine organic synthesis. Hydrogen is also used as part of the ingredients in the production of household cleaners (Navarro et al. 2007) as well as in the applications of aeronautics, astronautics and renewable-energy alternative vehicles (Hewu et al. 2013). Additionally, hydrogen is also utilized as an alternative fuel for energy and power in the industrial, commercial and domestic applications.

These miscellaneous uses of hydrogen do not greatly affect the total hydrogen consumption level (Dahiya and Chand 1987, Hewu et al. 2013), as their portion is relatively very small in comparison to the utilization in the top three large-scale industries. Taking hydrogen application as a transport fuel as an example, between July 2008 and August 2009, the passenger-carrying buses powered by hydrogen fuel cells in Beijing after traveling a total of $53,800 \mathrm{~km}$ consumed a total of only 5.33 tonnes of hydrogen (Hewu et al. 2013).

Not only hydrogen finds diversified applications, it is also versatile in its production technologies as it can be produced from various resources: fossil- and non-fossilbased. Approximately 48 million metric tonnes of the annual global industrial hydrogen production is based on fossil fuels (oil, natural gas and coal), which accounts for $95 \%$ of the total production, based on the statistics shown by the US Department of Energy from 1988 through to the 2000s (Figure 2) (Gaudernack, 1998, Ewan and Allen 2005, Navarro et al. 2007). Based on the consumption trend seen earlier, it is very interesting to note that the total hydrogen utilized by the large-scale industrial sectors is also around $95 \%$. This means that by total demand-supply average,

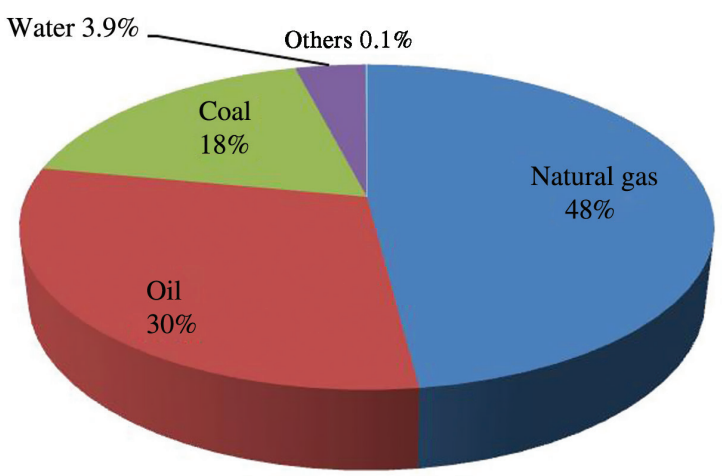

Figure 2: Sources distribution in total industrial hydrogen production of 500 billion $\mathrm{N} \mathrm{m}^{3}$ /year (Gaudernack 1998, Ewan and Allen 2005). 
the requirement for hydrogen volume in these sectors and applications, in principal, can be fulfilled by the hydrogen produced from the fossil-based resources.

In hydrogen production, fossil resources can come from natural gas, oil and coal, whereas non-fossil resources can be derived from water, biomass and solid wastes. The infrastructures for the supply of these feedstocks can therefore be built according to what are available in the regions (Barreto et al. 2003). Different technologies have been developed to process different feedstocks in order to "extract" the hydrogen out. In general, natural gas is processed through the conventional catalytic operations. Light oil such as naphtha can be catalytically processed similarly as natural gas but some technologies are noncatalytic. Coal is processed through gasification (Conte et al. 2001).

Only a small proportion of hydrogen is produced from non-fossil resources. Biomass and solid wastes are processed through gasification similar to coal. Hydrogen derived from water, on the other hand, is produced through electrolysis, which can be powered by conventional fossil fuels, or alternative renewable power sources such as solar, wind, hydropower and nuclear power (Conte et al. 2001).

It is predicted that in the near future, fossil fuels will still be the primary resources for hydrogen production (Gaudernack 1998, Navarro et al. 2007). A survey conducted by Barreto et al. (2002) based on the published literature and public databases (Figure 3) shows that for the capacity of hydrogen production of beyond 1.0 million $\mathrm{N} \mathrm{m}^{3}$ /day, steam reforming of natural gas (methane) offers the least investment cost as compared to other technologies. Water electrolysis, whilst investment cost can also be low, is only capable of producing hydrogen in significantly small quantities.

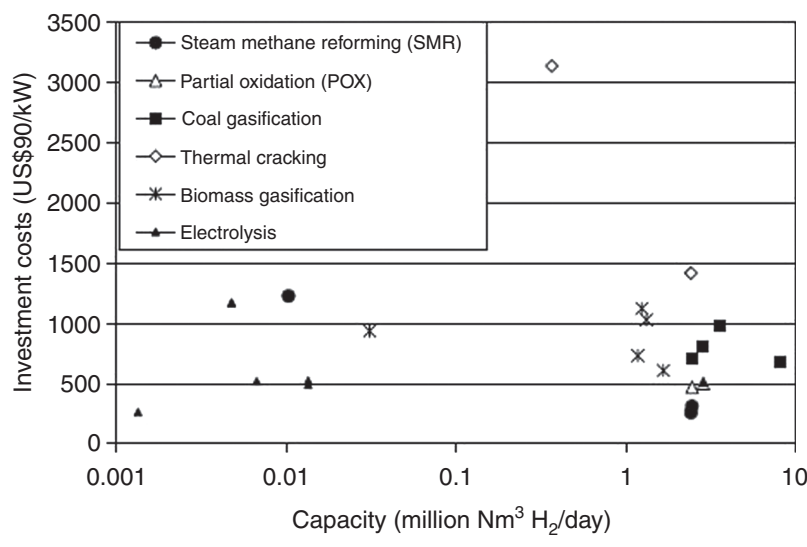

Figure 3: Survey conducted by Barreto et al. (2002) on investment cost of hydrogen plants of various production capacities.
The hydrogen production technologies from natural gas in general have been around for decades and are highly efficient in large-scale operation (Hewu et al. 2013). Based on the above statistical data and investment costs analysis, the scope of this paper is therefore emphasized on the relatively recent development in the research activities related to the conventional catalytic hydrocarbon processing technologies for the production of hydrogen derived from natural gas (methane), which caters for close to half of the total hydrogen production resources. Before that, an overview of various applications of hydrogen will be presented.

\section{Hydrogen applications}

Hydrogen is traded on the market in liquefied form or compressed gas in cylinders, and some supplies are transferred via pipeline. Most hydrogen in chemical production and refinery processes is produced in and consumed by the same plants. A very large proportion of the world's hydrogen volumes are being used in the top three largescale industrial processes (i.e. synthesis of ammonia and methanol, and petroleum refining). The analysis of the magnitude of the hydrogen volume consumed in these sectors will be briefly discussed. The hydrogen used in several smaller-scale manufacturing industries will also be presented.

We will also discuss the trend of hydrogen used as fuels for industrial, commercial and domestic consumptions. An overview of hydrogen used as an energy carrier in fuel cells for generating electricity and powering the hydrogen vehicles, as well as in spacecraft application, will also be presented to appreciate the use of this highly useful element that will shape our future.

\subsection{Hydroprocessing in petroleum refineries}

Hydrogen plays a role as a reactant in the refinery process where it is used in hydroprocessing. Hydroprocessing includes hydrocracking of heavy fractions, and removal of sulfur and other contaminants through hydrofining. The amount of hydrogen consumed by different refineries varies depending on the crude quality (i.e. level of sulfur and other contaminants contents) and characteristics (e.g. heavier crude requires a higher volume of hydrogen for hydrocracking) (Chernyi and Feigin 1968). Around $378,326,000$ tonnes of crude was processed in China in 2007 , consuming up to $1,700,000$ tonnes of hydrogen, out 
Table 1: Typical hydrogen consumption in various hydroprocessing stages in a typical refinery.

\begin{tabular}{lr}
\hline Hydroprocessing & $\begin{array}{r}\mathbf{H}_{2} \text { consumption in wt\% } \\
\text { relative to crude oil feed }\end{array}$ \\
\hline Hydrofining & 0.01 \\
$\quad$ Straight run naphtha & $0.05-0.1$ \\
Cracked naphtha & 0.04 \\
From low sulfur diesel feed to & 0.05 \\
< 500 ppm diesel product & \\
From high sulfur diesel feed to & \\
$>500$ ppm diesel product & $0.5-0.8$ \\
Hydrocracking & \\
$\quad$ Vacuum gasoil & \\
\hline
\end{tabular}

Source: Castaneda et al. 2011.

of which 0.02 tonne was used in hydrocracking and 0.01 tonne in hydrofining, in every tonne of crude oil processed (Hewu et al. 2013).

Castaneda et al. (2011) reviewed approaches and techniques used to calculate hydrogen consumption required by a refinery, with the interest to optimize its utilization in both the hydroprocessing processes; the hydrofining and hydrocracking. The data presented in Table 1 are reproduced from Castaneda et al. (2011) to indicate typical hydrogen consumption in various processes in a typical refinery. Note that the large hydrogen consumption in hydrocracking of vacuum distillate increases the $\mathrm{H} / \mathrm{C}$ ratio of the hydrocracker products relative to the hydrocracker feed, on top of utilization in hydrodesulfurization.

\subsubsection{Hydrocracking}

In the crude oil components, the higher boiling point fractions where the hydrocarbons are heavier are cracked into smaller chains upon heating. These smaller chains are hydrogen deficient upon cracking, and hence, they are instable. Hydrogen is added through catalytic hydrogenation (Dahiya and Chand 1987). The whole process is called hydrocracking, which is a simultaneous process of cracking and hydrogenation of hydrocarbons to break carboncarbon bonds, and hence reduce molecular weight for higher yield production of refined and higher $\mathrm{H} / \mathrm{C}$ ratio fuel products (Ramachandran and Menon 1998). The resulted fuel products have identical properties to those of gasoline (typical chain of $\mathrm{C}_{5}-\mathrm{C}_{10}$ ), which has the $\mathrm{H} / \mathrm{C}$ ratio between 2.0 and 2.2 (Dahiya and Chand 1987).

In the event where the light crude supply drops, refiners have no other choices but to process more viscous and heavier crude oils that are of lower $\mathrm{H} / \mathrm{C}$ ratios, which in turn increases the requirement for hydrogen in the hydrocracking. The hydrogen requirement for hydrocracking varies depending on the feed composition, typically in the range of 1000 to 2500 standard cubic feet (SCF) per barrel of the crude processed (Dahiya and Chand 1987).

\subsubsection{Hydrofining}

Hydrofining is the technology used in refineries to upgrade oils with high impurities (Martínez and Ancheyta 2014). Sulfur, which is omnipresent in crude oil, is one of the main sources of particulates or soot emissions (Đukanović et al. 2013), as well as sulfur dioxide, a gaseous pollutant commonly associated with acid rain (Paez et al. 2015). In the hydrofining process, sulfur is removed from petroleum products in the form of hydrogen sulfide gas, which is then reacted with a base such as lime or lime stone to neutralize and stabilize the acidic compound to calcium sulfide. In general, at least $500 \mathrm{SCF}$ of hydrogen is required for sulfur removal per one barrel of crude, depending on the sulfur contents (Dahiya and Chand 1987).

The current total sulfur content limit in transportation fuels such as gasoline and diesel in the EU, USA and some other parts of the world varies, where it is legislated at 10, 15 or 50 wt. ppm. Some countries still permit sulfur concentration limits of as high as $1000 \mathrm{ppm}$. Whilst compression ignition diesel engines are efficient in terms of fuel consumption, they adversely contribute to environmentally harmful emissions. Therefore, this has demanded the refineries to maximize the production yield of ultralow sulfur diesel fuel (Đukanović et al. 2013). As for the gasoline, a review was made by Paez et al. (2015) based on TIER 3 of Transportation Impact Environmental Review of the US Environmental Protection Agency. TIER 3 establishes new standards in emissions cutting from light-duty vehicles, expecting to reduce sulfur content of gasoline from $80-30$ ppm currently to $10 \mathrm{ppm}$.

In general, the sulfur content in a crude and the crude's density have a close relationship, and the density has a close connection with the crude's fractional compositions, as can be seen in Figure 4, where the data collected from Ural-Volga crudes were taken as an example. The light component consists of gas (fraction 1) and high boiling fraction (fraction 2) undergoes straight-run distillation to recover the products, called straight-run gasoline and diesel. The sulfur contained in the crude is distributed unevenly, where $60-70 \%$ sulfur concentrates in fractions 1 and 2. The distribution of sulfur in the secondary-processed products, called catalytically-cracked (fraction 3) and thermal-contact-cracked (fraction 4) gasoline and 


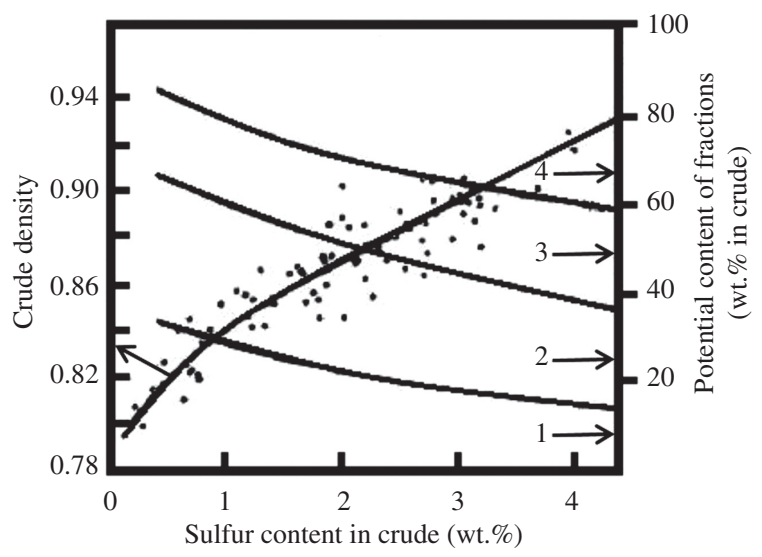

Figure 4: Left axis: sulfur content in crude as a function of crude density; right axis: crude fractions as a function of the crude density and sulfur content in the crude: (1) fraction with initial boiling point (IBP) of $180^{\circ} \mathrm{C}$, (2) fraction with IBP $180-350^{\circ} \mathrm{C}$, (3) fraction with IBP $350-500^{\circ} \mathrm{C}$ and (4) fraction with IBP $500^{\circ} \mathrm{C}$ (Chernyi and Feigin 1968).

diesel fuels, depends on the processing type (Chernyi and Feigin 1968).

Higher sulfur content in the crude gives a higher content of gasoline and diesel fuels obtained from both the straight-run distillation and the secondary processes, and hence, the desulfurization of these fuels requires a greater hydrogen volume. Figure 5 indicates the amount of hydrogen required in the hydrofining of the gasoline and diesel fuel, in relation to the sulfur content in the crude,

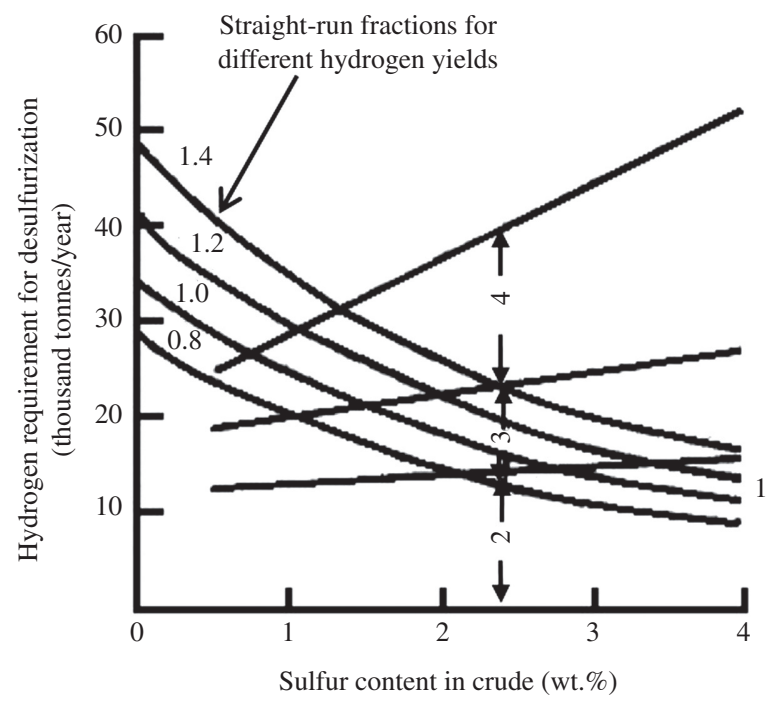

Figure 5: (1) Hydrogen production via catalytic reforming of straightrun fractions. (2, 3 and 4) Hydrogen consumption in hydrofining of gasoline and diesel fuels from straight-run fractions, catalytic cracking and thermal-contact cracking, respectively, in relation to crude's sulfur content (Chernyi and Feigin 1968). for a refinery processing 12 million tonnes of crude. Note that hydrogen is also being produced via catalytic reforming of the straight-run fractions, shown by trend line 1 . The trend in Figure 4 shows that the volume fraction of light components (straight-run fractions) in the crude decreases with the increase in the crude's sulfur content. With the decrease in the straight-run fractions, the hydrogen production via the catalytic reforming drops with the increase in the crude's sulfur content. On the other hand, the hydrogen consumption increases due to increased requirements in the hydrofining processes (Chernyi and Feigin 1968).

\subsection{Ammonia synthesis}

The Haber-Bosch ammonia production process started from a discovery of the chemical engineering foundations to synthesize ammonia from its elements in the laboratory by Fritz Haber, followed by an innovation by Carl Bosch who brought the production up to an industrial scale. Hydrogen is used in synthesis of ammonia $\left(\mathrm{NH}_{3}\right)$ as raw material through an exothermic process carried out in a 3 to 1 molar ratio reaction with nitrogen. The reaction proceeds with high yields in the presence of iron catalysts.

An interesting article featured in Nature Geoscience (2008) entitled "How a century of ammonia synthesis changed the world" (Erisman et al. 2008) discusses the significance of the Haber-Bosch process discovery in saving billions of people from hunger, due to the fact that fertilizers made from ammonia are mostly responsible in the expansion of agricultural activities for feeding the growing population in the world (Dahiya and Chand 1987).

Theoretically, the production of a tonne of ammonia requires an amount of approximately 0.18 tonnes of hydrogen (Hewu et al. 2013), which equals more than 30,000 SCF of natural gas (Dahiya and Chand 1987). In China, for example, an amount of 27,000,000 tonnes of ammonia was produced in 1997, which consumed 5,000,000 tonnes of hydrogen for synthesis. After more than 10 years due to the growing population, the numbers almost doubled up in 2008, where an amount of 51,589,000 tonnes of ammonia was produced using 9,411,900 tonnes of hydrogen (Hewu et al. 2013).

\subsection{Methanol synthesis}

Methanol is an important chemical used as a chemical storage carrier (Kobl et al. 2016, Xu et al. 2016), as well as in the transesterification process in biodiesel manufacturing 
(Novinson 2004). Methanol synthesis from CO follows the reaction

$$
\mathrm{CO}+2 \mathrm{H}_{2} \leftrightarrow \mathrm{CH}_{3} \mathrm{OH}
$$

Approximately 0.125 tonnes of hydrogen is required to synthesize 1 tonne of methanol. Over 20\% of the world's methanol supply is met by China. In 1995, an estimation of 200,000 tonnes of hydrogen was consumed in producing 1,500,000 tonnes of methanol. Amazingly, in less than 15 years, the output of methanol in China amounted to $10,367,700$ tonnes in 2008, consuming $1,310,000$ tonnes of hydrogen (Hewu et al. 2013).

\subsection{Other industries}

Other than the three main industries mentioned above, hydrogen is also consumed in other industries as a reactant in various manufacturing and production plants, in small amounts. In addition, syngas can also supplement the demand for gasoline and fuels by conversion through Fischer-Tropsch synthesis (FTS), an emerging gas-toliquid technology in the production of synthetic fuels.

\subsubsection{Manufacturing and production industries}

In the edible oils industry, hydrogen is used for hydrogenation of the edible oils to decrease the degree of unsaturated fats and increase the melting point such that the oils become a semi-solid at ambient temperature, for making margarine as an example. Hydrogenation, which takes place in the presence of nickel catalysts, also enhances the resistance to oxidation so that the food produced can be preserved longer (Dahiya and Chand 1987, Ramachandran and Menon 1998).

Whilst carbon is a good reducing agent to reduce metal oxides by combining with oxygen and forming gaseous oxides that escape away without further separation, hydrogen is an alternative reducing agent in metallurgical industry where carbon is undesirable. In tungsten manufacturing, for example, the presence of carbon makes the metal brittle, and hence, hydrogen is a better option (Dahiya and Chand 1987).

In electronics industry, wafer and circuit manufacturers use hydrogen as a reducing agent in the epitaxial growth of polysilicon, where silicon tetrachloride is reduced to silicon. In float glass manufacturing, the glass typically floats on a tin bath, and in order to prevent the oxidation of the molten tin bath, hydrogen is used as an oxygen scavenger in a mixture of $4 \%$ hydrogen in nitrogen (Ramachandran and Menon 1998).

\subsubsection{Fischer-Tropsch synthesis}

The premium pricing of gasoline and diesel fuels depends on their rating of research octane number (RON) and cetane number, respectively. Gasoline of a high RON would consist of highly branched alkanes, while diesel of a high cetane rating would consist of essentially linear alkanes. For example, $i$-octane (2,2,4-methyl pentane) has an RON of 100 and $n$-hexadecane has a cetane number of 100 (Dry 2002).

Engine fuels produced from crude oil distillation typically contain high amount of aromatics, organic sulfur and nitrogen. These compounds are environmentally undesirable. Furthermore, the aromatics decrease the cetane number, although at the same time increase the gasoline RON. Therefore, the diesel cut requires rigorous treatment with hydrogen to convert the aromatics to naphthenes as well as for hydrofining to bring down the sulfur and nitrogen contents. Despite the rigorous hydroprocessing, the cetane number is still not high enough when compared with that of linear alkanes (Dry 2002).

FTS coupled with some downstream treatment stages produces high-quality engine fuels as a result of low content of aromatics and zero content of sulfur. Fischer-Tropsch is a catalytic process that takes place at $200-300^{\circ} \mathrm{C}$ and $10-60$ bars over iron and cobalt catalysts to convert syngas (mixture of $\mathrm{H}_{2}$ and $\mathrm{CO}$ ) to a mixture of complex multicomponent hydrocarbons, ranging from linear and branched hydrocarbons to oxygenated products, with linear paraffins and $\alpha$-olefins as the main products. The synthetic sulfur- and aromatics-free FTS products are emerging as a complete substitute to the conventional engine fuels produced by crude oil distillation. At the very least, they can be blended together in meeting new quality regulations that will be more stringent in the near future (Van Der Laan and Beenackers 1999).

\subsection{Hydrogen as an alternative fuel}

Hydrogen is produced mainly from fossil fuel resources such as natural gas, oil and coal. These fossil resources are also used as fuels for generating various forms of energy such as thermal and electricity, by combustion with oxygen. Hydrogen is considered a clean alternative fuel to the fossil fuels, as the combustion of hydrogen with oxygen produces water, unlike the oxidation of fossils that leads to greenhouse gas emissions (Dahiya and Chand 1987). Presently, the EU as the world's most significant importer of fossil fuels is globally leading in the transition to renewable energy (Apak et al. 2012). 
For decades, hydrogen has also been considered as an important alternative fuel (Apak et al. 2012). Hydrogen energy is in a chemical form and, therefore, for its utilization as a fuel in domestic, commercial, and industrial applications, or in automobiles and for generating electrical power, the chemical energy needs to be converted into usable forms of thermal, mechanical or electrical. Similar to other fossil fuels, the first step involves the conversion of hydrogen's chemical energy to thermal energy in the form of heat, via combustion with oxygen (Dahiya and Chand 1987).

\subsubsection{High-temperature non-catalytic combustion for electricity generation}

In electrical power plants, steam is generated by thermal or nuclear power, and the heat energy is converted in a turbine to motion power, to run the electrical generator. The oxidation of hydrogen as a fuel takes place at high temperature in the furnaces and combustors of the power plants. The fuel source from coal in the thermal power plants using coal-fired boilers can be supplemented with hydrogen, by replacing the oil support burners with hydrogen burners.

Some advantages of hydrogen as a substitute or a supplementary to fossil fuels (e.g. coal) include the elimination of (1) the corrosion and erosion problems in the boilers encountered when using coal due to the presence of impurities, and (2) the requirement to transport the coal to the power plant sites as the hydrogen gas can be supplied via underground pipelines.

In some electrical power plants, the electrical power produced can be stored for a later consumption through an interesting storing mechanism by having electrolytic plants installed at the site. The electrolysis process for producing hydrogen in the electrolytic plants is powered by the electrical power generated during peak hours. The electrolytically produced hydrogen is stored in metal hydride, as liquid hydrogen or as compressed hydrogen gas (Dahiya and Chand 1987).

\subsubsection{Low-temperature catalytic combustion for small household and domestic appliances}

Natural gas or liquefied petroleum gas that is being used for domestic and small-scale commercial applications, which account for about $20-30 \%$ of the primary energy consumption, can be substituted with hydrogen in the form of "town gas," transported via pipelines. The town gas has a composition of $50-80 \%$ hydrogen with the remaining balance being primarily carbon monoxide. Some of these applications apply combustion at ambient temperature in the presence of a catalyst, as the working principle. This catalytic combustion of hydrogen at room temperature is possible due to its low ignition energy $(0.02 \mathrm{~mJ})$. The exothermic reaction releases energy that is transferred via conduction and convection to heat an object or fluid that is then used for application in fuel-consuming devices for heating, cooking and electricity.

For instance, a catalytic burner made of catalyst impregnated heating panels provides the heat source for a flameless, safe cooking device. In household appliances such as fans and vacuum cleaners, the hydrogen fuel cells are used to generate the electricity needed for running them. In the application of heating homes that use hydrogen fuel, the need to exhaust the combustion product through a chimney is eliminated since the hydrogen combustion with oxygen in the air produces only water. Hence, good thermal efficiency can be achieved at a reduced construction cost (Dahiya and Chand 1987).

\subsection{Emerging applications of hydrogen fuel cells for electricity generation, and in vehicles and spacecraft}

Hydrogen is fast becoming the energy carrier of preference for a number of applications (Barreto et al.2003), and hence, the demand of hydrogen for running fuel cells is expected to grow in the next decade (Navarro et al. 2007). Fuel cells technology is well developed and has reached a level of maturity. The working principle in the fuel cells involves a conversion of chemical energy directly to electrical energy by combining the hydrogen fuel gas with oxygen from the air, without involving a combustion, producing only water and heat as the by-products (Dincer 2002).

Different types of fuel cells have been developed with different characteristics; among others include operating temperature, heat availability, power density, as well as tolerance to thermal cycling and fuel impurities, which make each of the technologies suitable for a particular application. Dincer (2002) presented the working principles of a list of fuel cells that are the most commonly used and well developed, along with their respective applications. The fuel cells include solid oxide electrolyte fuel cells, molten carbonate fuel cells, phosphoric acid fuel cells, proton exchange membrane fuel cells, unitized regenerative fuel cells, alkaline fuel cells (AFCs) and direct methanol fuel cells. The applications of fuel cells cover a wide range of sizes from hand-held computing and communication devices powered by miniature, circuit-like 
and easily "rechargeable" fuel cells, to ultra-light, very efficient and low-polluting cars powered by inexpensive low-temperature fuel cells, and finally fuel cells used as small distributed electricity generators (Barreto et al. 2003).

The United States enacted energy legislation under the Energy Policy Act of 2005 (Holt and Glover 2006), which was passed due to concerns raised in security of energy and the quality of the environment. According to Lokey (2007), the section on hydrogen in Title VIII in the Act provides a direction toward hydrogen as a substitute to the declining petroleum global supplies. In the provisions, an authorization of $\$ 3.3$ billion for FY 20062010 was allocated for research and development activities on a hydrogen and fuel cell, especially with increased attention to hydrogen fuel and fuel cell vehicles following the Hydrogen Fuel Initiative announced at the State of the Union Address in January 2003 (Holt and Glover 2006).

\subsubsection{Electricity generation}

The increasing interest in hydrogen energy has seen hydrogen as an energy carrier being manufactured for electricity. As presented in Apak et al. (2012), Seoul, Korea, is an example of a capital city that takes seriously the use of hydrogen energy for electricity. The aim in their new climate change master plan looks at expanding the country's renewable energy share from $1.5 \%$ to $20 \%$ between 2007 and 2030, which includes contribution of hydrogen energy of close to half of this share.

Fuel cells are regarded as clean power producers, as there are no emissions of the acid rain or smog producing pollutants, as they do not utilize the combustion of fossil fuels. In addition, they are considered as efficient power producers as they generate electricity in a simple step and at significantly lower temperatures relative to electricity production at conventional power plants, where the combustion of fossil fuels takes place at a high temperature for heat generation. A few steps are involved in conventional power production that prior to the generation of electricity, the produced heat energy is first converted to mechanical energy (Dincer 2002). In hydrogen-air fuel cells, the efficiency of the hydrogen chemical energy conversion to electrical energy can go as high as 80\% (Dahiya and Chand 1987).

\subsubsection{Vehicles and forklifts}

Andrews and Shabani (2012) envisioned hydrogen's role as a key in a sustainable energy economy for not only longer-term storage in electricity grids, but also in the range of road and rail vehicles as well as marine ships and air transport. Due to its non-polluting properties, hydrogen is used in internal combustion engines as fuel, similar to engines operated with petrol and diesel (Apak et al. 2012). An analysis by Lin et al. (2013) revealed that hydrogen vehicles, including hydrogen internal combustion engines and hydrogen fuel cells, possess great potential to reduce reliance on petroleum and thereby reduce greenhouse gas emissions. The hydrogen-fuelcell-powered electric vehicles have the potential to offer a sustainable solution to the renewable resources transportation market. The hydrogen system as a whole from distribution, refueling and on-board storage offers superiority over batteries recharged with grid power (Dincer 2002).

In transportation applications, hydrogen is supplied for consumption in fuel cells by several ways. One of the options is through the hydrogen production at central locations via small-scale natural gas steam reforming, biomass or coal pyrolysis or gasification, or water electrolysis powered by renewable solar, wind, hydro or geothermal energy, followed by its storage on board the vehicle as a gas or a cryogenic liquid, or stored in a solid carbon. Another example of an option is through the use of methanol as a hydrogen carrier where the methanol is chemically broken into hydrogen and carbon dioxide by a catalyst on the fuel-cell's membrane (Dincer 2002).

The largest opportunity for fuel cell technology in the transportation market is in the light-duty automotive applications. Most of the players in the automotive industry have at least introduced fuel cell vehicle programs in their portfolios. The prototype of vehicles powered by hydrogen fuel cells have been developed and launched by many of them (Dincer 2002, Navarro et al. 2007). A list of existing commercialized hydrogen fuel cells for transportation by various automakers can be found in Conte et al. (2001) for further readership.

In the heavy-duty transportation sector, the attractiveness of the hydrogen fuel cell systems, especially in meeting a zero emissions target, was discussed in a study carried out by Ally et al. (2015) based on the trends of energy use and emissions in the road transport sector in Australia. More interestingly, the study also discussed the capability of the hydrogen fuel cell in meeting the requirements for range, duty cycle or payload higher than that of battery-only vehicles. Andrews and Shabani (2012) shared the same view where hydrogen fuel cell vehicles were identified as the transportation mode for medium or long distance trips, while plugin battery electric vehicles are reserved for short trips. 
Operating the forklifts is an equally interesting application of fuel cells. In comparison with the batterypowered forklifts, the ones operated by fuel cells offer various advantages that include higher productivity due to elimination of battery changing that is time consuming. Additionally, they can be refueled very quickly at the hydrogen fueling stations around the site. Unlike the forklifts powered by batteries, fuel cells have a significant advantage of maintaining a constant voltage that does not drop toward the end of a shift or in cold sites. A typical fuel-cell forklift design has a fuel-cell stack that acts as the main power source. The power source is supplemented by the energy stored in a battery or super-capacitor during peak demand (Elgowainy et al. 2009).

\subsubsection{Space}

Hydrogen in liquid form is used in the aerospace industry. Cryogenic liquid hydrogen is used as a lightweight fuel to propel space shuttles, rockets and aircrafts. Additionally, since the 1960s, the electrical systems on the spacecraft have been powered by hydrogen fuel cells in which the process also produces water for the crew's drinking consumption (Dahiya and Chand 1987, Wu and Leu 2014). Cecere et al. (2014) presented the historical journey from the aerospace industry applications of hydrogen since its discovery, through to its current and future technology advancements in turbojet, ramjet, scramjet and rocket engines, for further readership.

The type of fuel cell used in the space missions by NASA is the AFC, which has a power generating efficiency as high as $70 \%$. Although AFCs are among the oldest and simplest type of fuel cells, their commercial applications are very costly. An AFC is made of porous carbon plates deposited with a catalyst as the electrodes, with potassium hydroxide as the electrolyte. The hydrogen gas fuel combines with the hydroxide ions at the anode to produce water vapor, which results in left-over electrons. The produced water and the electrons form the hydroxide ions at the cathode, and these ions are recycled back to the anode for interaction with hydrogen, and the cycle repeats (Dincer 2002).

\subsubsection{Issues pertaining to infrastructure requirements for enabling widespread hydrogen-powered appliances}

Despite all the attempts to increase the popularity of hydrogen fuel cell vehicles, an interesting thought was raised by Krumdieck and Dantas (2008). According to them, the process of substituting fossil fuels with renewable fuels is not simple and straightforward. Based on the feasible-sustainability concept, the whole network for the solution must take into account changes in land use, infrastructure provision and technology capability. Renewable energy transport, such as electric cars and hydrogen fuel cell cars whilst presently getting the hype as the solution to sustainable transport, requires challenging infrastructure considerations. The issues presented in this review are meant to put the widespread use of hydrogen-powered appliances into perspective without the intention to address the approaches and solutions on overcoming them.

In order to facilitate widespread adoption of hydrogen-powered appliances, the infrastructure to produce, transport, store and distribute the hydrogen must be well developed. Competitive small-scale decentralized hydrogen generation units need to be established, with distribution systems that are highly reliable and can meet the power quality standards need to be put in place (Barreto et al. 2003). An identification of the future locations of hydrogen plants will need to take technical, economic and political aspects into considerations due to the large space requirement. Land availability will depend on its topography and may compete with meeting other purposes such as vegetation for instance. In exploiting wind energy as another example, there are not many regions in the world that are suitable for large-area wind energy utilization. Most of the suitable regions are mountainous coastline, and hence, the installations of wind power system become impractical for both economic and ecological reasons (Nitsch and Voigt 1988).

\section{Research activities in hydrogen production technologies}

\subsection{Water electrolysis}

At a smaller scale, hydrogen can be produced by splitting water into oxygen and hydrogen via electrolysis, which accounts for approximately 3.9\% of the total hydrogen production, as seen in Figure 2 (Gaudernack 1998, Ewan and Allen 2005). Increased attention on considering renewable sources has also opened up pathways for utilization of hydropower, and solar and wind energy for hydrogen production. Based on the report by National Research Council and National Academy of Engineering of the National Academies entitled "The Hydrogen 
Economy: Opportunities, Costs, Barriers, and R\&D Needs” (Board on Energy and Environmental Systems National Research Council 2004), the Department of Energy of the United States has listed the future direction on research and development focus in electrolysis through initiatives toward reducing cost and enhancing the efficiency of the system through integration between electrolyzers with power derived from wind and solar energy. Hydropower serves mainly to replace the fossil fuels in the electrical power plants to meet the huge industrial demand for electricity, and hence, only a small portion is utilized for electrolytic hydrogen production (Nitsch and Voigt 1988).

Wind energy collected in remote windy regions presents an economically unlimited energy source. Solar energy on the other hand requires a consideration on the factors such as the availability of large amounts of radiation and the condition of the identified geographical areas, so that the construction and the operation of the solar plants can be done at low costs in order for them to be economical. Not only the total amount of radiation is crucial, the shares of the diffuse and direct radiation must also be taken into account in the feasibility evaluation of building a solar plant (Nitsch and Voigt 1988).

Hudson et al. (2009) reviewed methods that employ solar energy, namely, photovoltaic (PV) and photoelectrochemical (PEC). The PV technique is a process utilizing PV electricity generation where the electricity is generated first, followed by the electrolysis. Whilst being feasible, its efficiencies are limited. PEC, on the other hand, is a single-step process where solar light illuminating semiconducting photoelectrode produces electrons and holes, and hence dissociates the water. Wu and Leu (2014) presented several techniques of recovering hydrogen from water electrolysis in their review. Among others include high-temperature decomposition and the photo-biological process.

Marshall's group has been actively producing novel research in this area. One of their works demonstrated proton exchange membrane water electrolysis that offers various advantages in comparison to the traditional alkaline technologies in terms of energy efficiencies and hydrogen production rates (Marshall et al. 2007). Another study exhibited the use of electro-catalytic cobalt oxide layers to enhance the efficiency of water electrolysis cell (Mellsop et al. 2014).

\subsection{Gasification}

As seen in Figure 2, up to $18 \%$ of the total hydrogen production comes from coal, while a very small portion of $0.1 \%$ production is categorized as others, which could include biomass- and solid waste-based resources. Both of these fossil and non-fossil resources are consumed to produce hydrogen through gasification (Gaudernack 1998, Ewan and Allen 2005, Navarro et al. 2007).

Gasification is the main pathway of producing hydrogen using coal. Other than gasification, coal coking is another means of producing hydrogen. In gasification, coal is burned in the presence of oxygen (air) or vapor and converted into gaseous products where hydrogen is the main component, at a high temperature and a constant pressure, or under an elevated pressure. In coking, coal is heated to produce coke and coke oven gas by-product, at temperatures of $900-1000^{\circ} \mathrm{C}$ without the presence of air. Typically, in every 1 tonne of coal, approximately $300-350 \mathrm{~N} \mathrm{~m}^{3}$ of coke oven gas that has hydrogen content of up to $60 \%$ can be produced from the coking process. The remaining components of coke oven gas include $\mathrm{CO}$, unsaturated hydrocarbons, $\mathrm{CO}_{2}, \mathrm{O}_{2}$ and $\mathrm{N}_{2}$ at varied concentrations. The coke oven gas has a heat value of 17-19 MJ/ $/ \mathrm{N} \mathrm{m}^{3}$, which makes it a good fuel candidate in high-temperature industrial furnaces or as a town gas. In China, the majority of the hydrogen produced from coal is used for the synthesis of ammonia and methanol. For example, of 7.13 million tonnes of hydrogen produced from coal in 2007 , up to $78.5 \%$ was used for ammonia production, and slightly less than $15 \%$ was used for methanol production (Hewu et al. 2013).

Biomass has also received a lot of attention as the resource for hydrogen production. An overview and perspective of a system called biomass integrated gasification combined cycle with steam gasification was presented by Pang and Li (2006), for electricity and thermal energy generation from wood. Among other key areas for research work in this subject includes gasification performance optimization and capital cost minimization. For instance, a study undertaken by Pang's group (Saw et al. 2012) on steam gasification of mixtures of biomass sources demonstrated an increase in $\mathrm{H}_{2}$ and $\mathrm{CO}$ production as well as improvement in the $\mathrm{H}_{2} / \mathrm{CO}$ ratio in the fluidized bed gasifier when wood pellet mass was added with increasing load of dried sewage sludge called biosolids.

Hosseini and Wahid (2016) presented an overview of the hydrogen production technologies using biomass resources via biological and thermochemical processes. The biological conversion process includes photo-fermentation and water biophotolysis using algae. The thermochemical process is found to be superior due to its lower cost and higher efficiency compared to the biological process. It was also found that supercritical water gasification (SCWG) is a more cost-effective process compared 
to steam gasification. The SCWG process utilizes highly moisturized biomass directly in the gasification process, which eliminates a drying stage that is typically costly. In addition, the hydrogen is produced at high pressure, and, therefore, a relatively smaller energy amount is required to pressurize the gas in the storage tank.

\subsection{Conventional catalytic hydrocarbon processing technologies}

Based on the statistical data in Figure 2 and the investment costs analysis in Figure 3, the production of hydrogen derived from natural gas (methane) through conventional catalytic hydrocarbon processing technologies accounts for slightly below half of the total global hydrogen production, and hence, becomes the main focus of discussion in this review. In addition, these catalytic processes are also applicable in processing petroleum oil components such as naphtha as the resource, which accounts for $30 \%$ of the total production.

The most commonly used catalytic hydrocarbon conversion technologies for large-scale hydrogen production are the conventional steam methane reforming (SMR), partial oxidation of methane (POX) and autothermal reforming (ATR) (Gaudernack 1998, Holladay et al. 2009, Ciambelli et al. 2011). The average release of $\mathrm{CO}_{2}$ to the atmosphere of $0.6 \mathrm{~N} \mathrm{~m}^{3}$ in every $\mathrm{N} \mathrm{m}^{3}$ of hydrogen produced from fossil fuels (natural gas, oil and coal) corresponds to a global $\mathrm{CO}_{2}$ release of approximately $500 \mathrm{Mt}$ in a year, which is a considerably large amount of greenhouse gas. $\mathrm{CO}_{2}$ sequestration would reduce substantially the amount of the release but this comes with an exorbitant price. However, the cost increase is expected to be moderate in the case of hydrogen production from natural gas (Gaudernack 1998).

Hydrocarbon decomposition is included in this review not only because it has the potential to be industrialized in the future, but also because the technology produces clean hydrogen and eliminates the $\mathrm{CO}$ emissions. The objective of the methane (natural gas) decomposition process is to crack the hydrocarbon into hydrogen and carbon. The decomposition was originally employed for the production of carbon black used for energy storage, while hydrogen was produced as a by-product to supplement the fuel for the process (Gaudernack 1998, Muradov 2002).

Muradov (2002) presented the working principles of different types of hydrocarbon decomposition technologies currently being developed in a laboratory scale, among others include thermal (pyrolytic), plasma, photocatalytic and thermocatalytic decomposition. In this review, we are interested in the last type of hydrocarbon decomposition technology due to its advantage in generating carbon nanofibers (CNFs) or nanotubes as by-products that have the potential in various emerging applications (Teo et al. 2003).

Even though the catalytic natural gas processing technologies for hydrogen production have been around for many decades, there is always room for improvement in the form of improving the hydrogen output, minimizing the total energy consumption and reducing operating cost by avoiding problems such as carbon deposition in the process.

\subsubsection{Steam methane reforming}

This section presents an introduction to the commercial SMR process, and research efforts in understanding the catalytic process over various transitional metal catalysts, on different carrier materials, as well as process modifications to make the process effective. The thermodynamics and kinetics of the reactions involved, together with the transport processes of the process gas and molecules over the catalyst particles, are a separate topic of discussion, and hence not covered in this review.

Steam reforming is a principal process for hydrogen and synthesis gas production in the industry, where more than $80 \%$ of global ammonia production is based on the hydrogen produced by steam reforming (Mondal and Chandran 2014) prior to synthesis with nitrogen. The first step of the SMR process involves the reaction of methane with steam at $697-827^{\circ} \mathrm{C}$ to produce syngas (reaction (2)), which is a mixture of hydrogen and carbon monoxide. Water gas shift reaction (WGSR) then follows, where the $\mathrm{CO}$ produced in the first reaction reacts with steam and form hydrogen and carbon dioxide (reaction (3)). The overall SMR reaction is represented by the combined reaction (reaction (4)) (LeValley et al. 2015).

SMR:

$$
\mathrm{CH}_{4}+\mathrm{H}_{2} \mathrm{O} \leftrightarrow \mathrm{CO}+3 \mathrm{H}_{2}
$$

WGSR:

$$
\mathrm{CO}+\mathrm{H}_{2} \mathrm{O} \leftrightarrow \mathrm{CO}_{2}+\mathrm{H}_{2}
$$

Combined SMR and WGSR:

$$
\mathrm{CH}_{4}+2 \mathrm{H}_{2} \mathrm{O} \leftrightarrow \mathrm{CO}_{2}+4 \mathrm{H}_{2}
$$

The research undertaken in SMR has been quite fundamental, where most work involved catalytic performance study to improve the reaction conversion. 
Different interpretations of reaction kinetics presented in the literature were reviewed by Jones et al. (2008), and they appeared to follow a general consensus of the firstorder reaction with respect to methane.

Nickel-based catalysts are not just traditionally used for steam reforming (Jones et al. 2008), but have also been the most commonly used due to their adequately high activity and considerably lower cost compared to other metal catalysts (Wu et al. 2013). A study was conducted on SMR kinetics at varying $\mathrm{Ni} \%-\mathrm{Al}_{2} \mathrm{O}_{3}$ to investigate the effect of the Ni content (Kim et al. 2015). From the analysis, the activity was found to be higher at higher Ni loading, undoubtedly attributed to the higher number of Ni metal particles.

Nickel catalysts nevertheless possess the drawback of being prone to deactivation due to carbon deposition from hydrocarbon cracking, even when being operated at the conditions where steam-carbon ratios are anticipated to be thermodynamically outside the regime of carbon formation ( $\mathrm{Wu}$ et al. 2013), hence, inviting a number of studies to address and identify the order of reactivity of a series of transition metals for superiority comparison. $\mathrm{Ru}$, $\mathrm{Rh}, \mathrm{Pd}$, Ir and Pt are among the noble metals that have been demonstrated to provide good activity for SMR, but they are not justified cost-wise for use in industrial reformers (Jones et al. 2008).

Jones et al. (2008) conducted the experimental work to rank the steam reforming activity for $\mathrm{Ni}, \mathrm{Pt}, \mathrm{Ru}, \mathrm{Rh}, \mathrm{Ir}$ and $\mathrm{Pd}$ supported on $\mathrm{ZrO}_{2}$ and $\mathrm{Al}_{2} \mathrm{O}_{3}$, at $773 \mathrm{~K}$ and atmospheric pressure, which is a condition away from equilibrium. The activities were correlated to the uniformity and homogeneity of metal catalysts dispersion, by measuring the adsorption energies of hydrogenated atoms adsorbed on the pure metal surfaces. The approach was considered vital due to the entropic effects that are significant at the high steam reforming reaction temperatures. The technique allowed thermodynamic parameterization of the kinetic model for determination of the activities of the pure metals in terms of turn-over frequencies, which is the parameter to quantify catalyst activity measured by $\mathrm{mol}_{\text {reactant_reacted }} / \mathrm{s} . \mathrm{g}_{\text {catalyst }}$ (Fogler 1999). The relative catalyst reactivity was in agreement with other earlier publications in the order of $\mathrm{Ru}>\mathrm{Rh}>\mathrm{Ni}>\mathrm{Ir}>\mathrm{Pd}>\mathrm{Pt}$ from higher to lower activity at similar dispersion (Jones et al. 2008).

It has also been observed that catalytic research in SMR has evolved and progressed from activity investigations on pure metal to metal alloy catalysts. The addition of a second metal to the "traditional" nickel catalyst has been demonstrated to significantly modify the properties of nickel particles as a result of bimetallic surface alloy formation. Wu et al. (2013) were inspired to compile the studies on the use of bimetallic catalysts, by investigating catalytic activity and catalyst deactivation by carbon formation over modified nickel surfaces through formation of an alloy with a second metal from a series of noble and other metals including $\mathrm{Au}, \mathrm{Ag}, \mathrm{Sn}, \mathrm{Cu}, \mathrm{Co}, \mathrm{Mo}, \mathrm{Fe}, \mathrm{Gd}$ and B. In general, Ni/second-metal bimetallic catalysts had been proven to exhibit greater catalytic performance compared to monometallic nickel catalysts in terms of activity, resistance to coke deposition and metal particles' sintering and hydrogen selectivity.

Besides bimetallic alloy catalyst systems, studies have also been performed on composites of metal mixtures to improve SMR performance. For instance, a composite catalyst of nickel, cerium, zirconium and zinc was synthesized in a relatively recent study that integrated SMR with WGSR in the effort to bring down production costs (LeValley et al. 2015). Interestingly, the composite catalyst was designed to provide activity for both the SMR and WGSR. A significant finding was noted on the addition of zinc that resulted in reduced surface area, and hence, the activity of the SMR reaction, but on the other hand increased WGSR activity, based on the observed improvement in carbon dioxide selectivity, hydrogen production and resistance to carbon deposition. Additionally, this composite catalyst system is potentially valuable in lowtemperature SMR investigations, a condition which is less favorable for carbonaceous gases emission, based on the promising methane conversion and $\mathrm{CO}_{2}$ selectivity performance at a reaction temperature of $650^{\circ} \mathrm{C}$.

The fundamental catalytic study on SMR has focused on the effect of the metal catalyst addition as a promoter or surface modifier of the nickel catalyst with the aim of improving energy efficiency and reaction performance. Investigations have also included modifications to the catalyst support, which acts as the carrier, to meet the same objectives.

The carrier has its own specific role in the nickel catalyst activity. Ni on its own is not active, until it is distributed on a carrier. A carrier enhances the surface area of Ni and ensures that small Ni crystallites will not bind together and form larger crystals (thermal sintering). The carrier is designed to have a certain porosity to allow gas access to the entire available Ni surface. It is a stable, inert and mostly ceramic-based material where no activity for accelerating any undesired side reactions should be expected, and it must also not react chemically with any constituents of the process gas.

Having a high fusion point or high thermal stability is also an important criterion for selecting a carrier, as SMR is highly endothermic and takes place at very high temperatures (typical inlet temperature of $450-650^{\circ} \mathrm{C}$ 
and outlet temperature of $700-950^{\circ} \mathrm{C}$ ). However, carriers are typically acidic and the selection should also take into account their level of acidity. The acidity can cause hydrocarbon cracking activity that leads to coke (carbon) formation.

Antzara et al. (2016) evaluated SMR performance in chemical looping using a NiO-based catalyst supported on a series of oxygen transfer materials: $\mathrm{ZrO}_{2}, \mathrm{TiO}_{2}, \mathrm{SiO}_{2}, \mathrm{Al}_{2} \mathrm{O}_{3}$ and $\mathrm{NiAl}_{2} \mathrm{O}_{4}$ at a low temperature of $650^{\circ} \mathrm{C}$ and a steammethane ratio of $2: 1$. It was found that $\mathrm{NiO} / \mathrm{SiO}_{2}$ and $\mathrm{NiO} /$ $\mathrm{TiO}_{2}$ had low activity with less than $50 \%$ of the methane being converted in the beginning and eventually dropped to less than $10 \%$ methane conversion after $2 \mathrm{~h}$ on stream as they deactivated rapidly. $\mathrm{NiO} / \mathrm{ZrO}_{2}, \mathrm{NiO} / \mathrm{Al}_{2} \mathrm{O}_{3}$ and $\mathrm{NiO} /$ $\mathrm{NiAl}_{2} \mathrm{O}_{4}$ exhibited good catalytic activity with an initial methane conversion of more than $80 \%$, but only $\mathrm{NiO}$ supported on $\mathrm{ZrO}_{2}$ demonstrated good stability. On the other hand, $\mathrm{NiO}$ supported on $\mathrm{Al}_{2} \mathrm{O}_{3}$ and $\mathrm{NiAl}_{2} \mathrm{O}_{4}$ exhibited high deactivation that led to a drop in methane conversion to $59 \%$ and $63 \%$, respectively, at the test end. This superior stability of $\mathrm{ZrO}_{2}$ is consistent with an earlier research work by the same group of researchers, investigating $\mathrm{NiO}$ supported on $\mathrm{Al}_{2} \mathrm{O}_{3}$ and $\mathrm{ZrO}_{2}$ (Shen and Lua 2015), in experiments carried out in multiple cycles of reduction/ reforming at $650^{\circ} \mathrm{C}$ and reoxidation at $850^{\circ} \mathrm{C}$.

In the following study presented by Kho et al. (2016), which was carried out recently, a promising lowtemperature SMR operation was demonstrated on titanium dioxide-supported and silica-supported nickel catalysts, $\mathrm{Ni} / \mathrm{TiO}_{2}$ and $\mathrm{Ni} / \mathrm{SiO}_{2}$. The former offered stability and effective hydrogen production at $500^{\circ} \mathrm{C}$, with methane conversion of $45 \%$ at a steam-methane ratio of $3: 1$. This is in alignment with the study by Antzara et al. (2016) that demonstrated a similar level of activity at $650^{\circ} \mathrm{C}$, which indicates that an even lower operating temperature could be achieved in SMR using nickel catalyst supported on titanium dioxide without affecting its level of activity, by increasing the steam-methane ratio. The activity performance at low temperature was attributed to stronger support interaction with nickel species. In comparison to nickel supported on conventional inert oxide (silica), the reaction for hydrogen production was more active via WGSR, instead of SMR, due to a weaker nickel-support interaction.

One significant research area in SMR of late is the modification of the catalyst support substrate to a monolith. As commonly practiced, the SMR reaction takes place in metal tubes containing a packed bed of typically $\mathrm{Ni} / \mathrm{Al}_{2} \mathrm{O}_{3}$ particulate. The slow and highly endothermic reaction requires large amounts of heat supplied via external firing of reformer tube, in which conventionally the heat transfer is ineffective due to poor convection from the reactant species to the active catalyst sites. Monolithic support substrates have been introduced where the catalysts are deposited on it and heat transfer efficiency is hence improved via the enhanced thermal conductivity of the monoliths, transferring the heat from the tube wall to the catalyst sites. This efficient process leads to process intensification where a higher reaction rate is achieved in a smaller reactor at a significantly lower pressure drop. Furthermore, the monolith has improved the mechanical integrity of the catalytic system. Giroux et al. (2005) and Heck et al. (2001) presented a discussion on the advantages of this promising catalytic support system.

Other than the fundamental catalytic performance investigations through modifications of nickel catalyst surfaces and catalyst supports, knowledge in chemical engineering has also been applied in modifying the so-called conventional SMR process design as well as in designing new reactor configurations, for reaction improvement.

Zhu et al. (2015) presented a novel work applying $\mathrm{CaO}$ sorption enhanced SMR (SESMR) for thermal promotion of hydrogen production. The system was combined with chemical looping combustion (CLC) for $\mathrm{CO}_{2}$ capture, instead of the commonly used furnace. The design was developed through Aspen Plus simulation. CLC employment served to function as the provider of the necessary heat for SESMR, while at the same time achieving inherent separation of $\mathrm{CO}_{2}$ without extra consumption of energy. The developed configuration exhibited advantages over the existing commercial SMR process, most notably on hydrogen purification, without the need for an additional process to remove impurities, while being more energy efficient. $\mathrm{CO}$ and $\mathrm{CO}_{2}$ concentrations were decreased alongside with the progress of the reaction, from $0.2 \%$ and $2.4 \%$ down to ppm level.

With the objectives to reduce energy consumption and carbon formation as well as to improve reaction performance, Kyriakou et al. (2016) investigated the feasibility of SMR at low temperatures $\left(450-650^{\circ} \mathrm{C}\right)$ by employing a Ni-BZCY72/BZCY72/Cu proton conducting membrane reactor (MR). The MR had the flexibility to perform as a typical reformer operation by conducting the test under open-circuit conditions as the first step. Membrane-based operation took place in the same system, when hydrogen produced from the first step was electrochemically transported from the anode made of Ni-BZCY72 to the $\mathrm{Cu}$ cathode. The membrane operating mode was observed to have demonstrated further improvement in methane conversion and hydrogen yield, after the first open-circuit step. 
Another novel reactor design was developed by Choi et al. (2016) by elimination of the use of catalysts, hence, eliminating the risk of deteriorating reaction performance due to catalyst deactivation. In addition, it was reported that hydrogen yield of higher than $70 \%$ was achieved at atmospheric pressure, in the developed microwave system, composed of mainly a $2.45 \mathrm{GHz}$ microwave plasma torch and a plasma nozzle, that generated a steam plasma at which SMR took place. The need for catalysts was eliminated as the high-temperature plasma flame enhanced the reaction rate while the steam microwave plasma excited the activity of the reacting species.

SMR research has been focused on fundamental work in various types of metal catalysts aimed at achieving an energy-efficient operation at high reaction performance and minimal carbon deposit, which typically include the examination using various mono- and bi-metal catalysts, as well as modifications of the catalyst support and process engineering design. Table 2 summarizes the work reviewed in this paper.

\subsubsection{Partial oxidation of methane}

In the POX process, the fuel is combusted with oxygen to produce syngas, following exothermic reactions (5) and (6) (Muradov 2002, Dedov et al. 2015). POX is favorable in comparison to steam reforming, for the use in FisherTropsch and methanol synthesis (Dedov et al. 2015):

$$
\begin{gathered}
\mathrm{CH}_{4}+0.5 \mathrm{O}_{2} \rightarrow \mathrm{CO}+2 \mathrm{H}_{2} \\
\mathrm{CH}_{4}+\mathrm{O}_{2} \rightarrow \mathrm{CO}_{2}+2 \mathrm{H}_{2}
\end{gathered}
$$

In general, the partial oxidation process can take a wide range of hydrocarbon feedstocks. Any heavy hydrocarbons including heavy residual oils and coal can be processed by non-catalytic partial oxidation at high temperatures of around $1100-1500^{\circ} \mathrm{C}$. On the other hand, the catalytic partial oxidation of light hydrocarbon fuels such as natural gas and naphtha takes place at significantly lower range temperatures of around $600-900^{\circ} \mathrm{C}$ (Muradov 2002).

The production of hydrogen by means of partial oxidation can be derived from various hydrocarbon molecules as well as biomaterials. Catalyst activity in the partial oxidation of bioethanol was studied by Kraleva et al. (2015) over xNiAlZn catalysts at various Ni loadings, while Wang et al. (2016) investigated partial oxidation of a mixture of phenol, acetic acid and naphthalene in supercritical water.

As far as POX is concerned, active investigations have been carried out by researchers on various transitional metal catalysts to understand their performance and conditions toward achieving the main objectives of improving $\mathrm{H}_{2}$ and $\mathrm{CO}$ (syngas) selectivity, increasing hydrogen yield and eliminating carbon deposition. Efforts include the addition of support materials to the metal catalysts, such as mixed perovskite-like oxides to minimize carbon formation, the use of monolithic support to improve selectivity and reactor modifications to increase product yield.

In two very recent works investigating catalytic activity and coke formation at varied operating parameters, nickel catalysts deposited on nanocrystalline $\mathrm{CeO}_{2}$ and $\mathrm{Al}_{2} \mathrm{O}_{3}$ supports were used in POX (Peymani et al. 2016) and propane (Peymani et al. 2017), respectively. The nickel catalysts prepared by an impregnation technique that exhibited a high surface area, and a mesoporous structure with very uniform size distribution, were varied in their loading content, where the highest catalytic activity was observed on $10 \% \mathrm{Ni} / \mathrm{CeO}_{2}$ and $7.5 \% \mathrm{Ni} / \mathrm{Al}_{2} \mathrm{O}_{3}$. With a rise in the reaction temperature, the amount of carbon accumulation increased slightly in the case of $\mathrm{CeO}_{2}$ in methane partial oxidation, but decreased slightly in the case of $\mathrm{Al}_{2} \mathrm{O}_{3}$ on propane. Nonetheless, the deposited carbon amount decreased with the increase in the oxygen-methane molar ratio from 0.25 to 0.75 in both cases, together with an improved methane conversion in the case of methane partial oxidation. Other factors such as varied calcination and reduction temperatures during the catalyst pretreatment were also studied, to understand their effect on the hydrocarbon conversion. It was found that the methane conversion dropped with the increase in the calcination temperature, while propane conversion improved with the increase in the reduction temperature.

In the efforts of mitigating carbon deposition that can deactivate the catalysts, initiatives on studying the effect of a second metal have been made. For instance, very little carbon was formed during catalytic partial oxidation reaction tests using Ni-Ru bimetallic catalyst as compared to when single metal nickel catalysts were used (Velasco et al. 2015). Another example is that the addition of $\mathrm{CoO}$ to $\mathrm{ZrO}_{2}$ supported $\mathrm{NiO}$ catalyst, which has also proven to significantly reduce carbon deposition (Choudhary et al. 1998). Mixed perovskite-like oxides (Dedov et al. 2015, Palcheva et al. 2015) when being added to the catalysts served to improve catalyst activity due to their ability to generate well-dispersed metal catalyst particles during reduction, stabilizing the small metal catalyst clusters.

In reaction performance investigations, Diehm and Deutschmann (2014) and Figen and Baykara (2015) presented studies of catalytic methane partial oxidation using monolithic catalysts. Diehm and Deutschmann (2014) studied performance of the reaction over palladium- and 


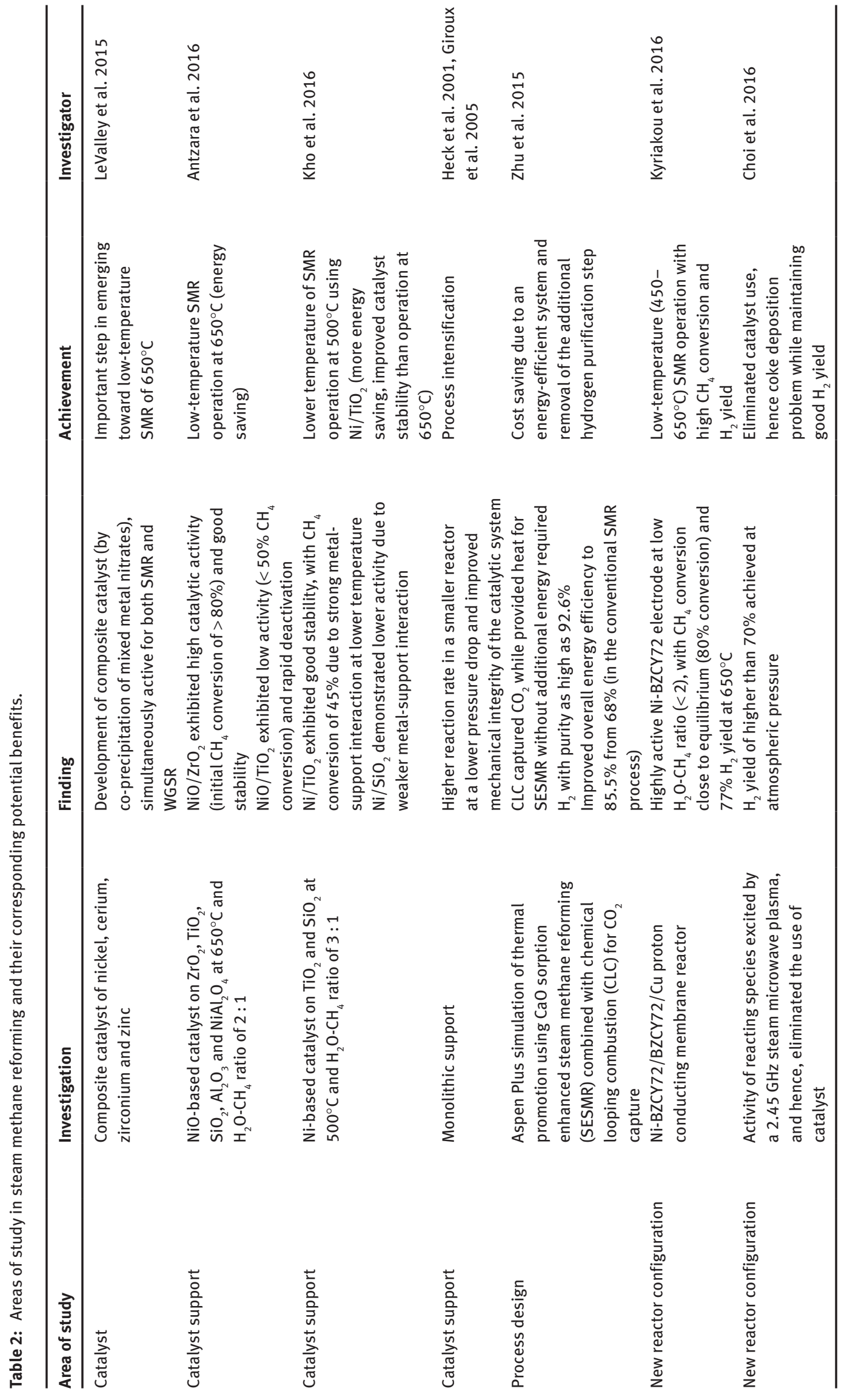


rhodium-coated alumina monoliths, while Figen and Baykara (2015) investigated reaction performance over $\mathrm{Co}, \mathrm{Co}-\mathrm{Ni}, \mathrm{Co}-\mathrm{Ru}, \mathrm{Co}-\mathrm{Ni}-\mathrm{Ru}$ and $\mathrm{Ni}$ catalysts supported on cordierite monoliths. Neagoe et al. (2016) demonstrated more effective oxidation of methane in $\mathrm{O}_{2} / \mathrm{Ar}$ mixtures by observing higher selectivity of both $\mathrm{CO}$ and $\mathrm{H}_{2}$ at $900^{\circ} \mathrm{C}$ and 20 bar using Pt supported on iron-chromium alloy (FeCralloy) woven metal, when compared with commercial Pt-gauze or $\mathrm{Pt} / \mathrm{Rh}$ gauze.

Through a new design on reactor configuration, a numerical simulation study by Chen et al. (2010) demonstrated an achievement in process intensification where the reaction was run over a rhodium catalyst bed embedded at the center of a Swiss-roll structure reactor. The simulation demonstrated improvement in methane conversion and hydrogen yield of higher than $10 \%$ in POX through preheating of reactants using waste heat recovered from hydrogen gas. This achievement was made possible by the exchanger design in the Swiss-roll structure where the number of turns in the reactor was increased and the gas hourly space velocity (GHSV) was brought down for the reactants to interact effectively with the catalyst bed.

The performance of methane partial oxidation in an MR has also attracted researchers to investigate the options of membrane material for the purpose of process intensification and hydrogen production improvement. Chibane et al. (2011) conducted theoretical analysis of Pd-MR performance through periodic feed composition and carrier gas, which was proven to have produced significantly superior level of methane conversion and hydrogen recovery, in comparison to steady state feed. Song et al. (2015) performed an experimental comparison between different membrane materials, namely, perovskite oxides membrane and conventional dense membrane. The former exhibited mixed ionic and electronic conductivities, indicating higher stability and better performance as it possesses high oxygen permeation flux, and hence, higher methane conversion efficiency. A model developed based on a multi-layer asymmetric oxygen-permeable membrane by Shelepova et al. (2016) was simulated to determine the process parameters such as temperature and gas flow rates, and membrane parameters such as pore diameter of porous layer and thickness of porous layer, at which methane conversion was the highest and syngas selectivity was the best.

Air Products and Chemicals in collaboration with the Department of Energy of the United States through Ceramatec have developed ceramic ion transport membranes for separating oxygen of high purity from the air and conducting the ionic oxygen at high temperatures, particularly economical for the use in partial oxidation processes due to high level of oxygen purity and possibility of high flux transfer of oxygen. The technology exhibits a process intensification initiative where air separation and the reacting system are uniquely integrated, attractive for compact design that has the potential to reduce significantly the construction cost of large-scale units.

An article by Dyer et al. (2000) presented this membrane technology development and cited its corresponding registered patents for further reference. In the early $2000 \mathrm{~s}$ when the concept was introduced and proven at a laboratory scale, some technical hurdles have yet to be overcome in the efforts to commercialize the units in an industrial scale. The challenges include the lack of design that can integrate successfully the engineering processes with the ITM, the unavailability of an economical technology for the ceramic membrane fabrication, and the undeveloped potentially stable ITM materials that can meet the required performance characteristics. Fast forward to 2014, Miller et al. (2014) presented the advancement of the original ITM technology for syngas production through the addition of porous layers on the membrane where it was demonstrated that the highest oxygen fluxes were achieved due to an increase in the membrane's surface area. Whilst the technology offers huge potential for cost reduction in syngas production processes, the technical hurdles have not been completely overcome in materializing the technology application at an industrial scale, and in fact the technology is no longer pursued by Air Products.

An interesting model was developed by Dashliborun et al. (2013) using a one-dimensional steady state nonisothermal model to investigate POX performance using a side feeding air injection reactor (SFR) and compare with a fixed bed reactor (FBR) and an MR. The simulated results demonstrated enhancement of the reaction performance with the increase in the number of air injections in the SFR. With only a single air injection, the outlet temperature in the SFR already showed a reduction of close to $200 \mathrm{~K}$ from $1269 \mathrm{~K}$ in the FBR. Hydrogen selectivity improved to $53 \%$ when the number of air injections in the SFR was increased up to 3, from 50\% in the MR. This revealed that the performance was equivalent, and hence, the MR, which was associated with high process cost, could now be potentially substituted. The finding also led to a creation of controllable operating temperature and enhancement of hydrogen selectivity, which would potentially eliminate the problems of high operating temperature in FBR, hence, reduction in the operational cost through energy saving.

Another interesting reactor configuration in the experimental study of POX is the microchannel reactor (Makarshin et al. 2015). It was demonstrated that the temperature profile along the FeCralloy microchannel plate 
length deposited with Ni-Pt/LaCeZrO catalyst was not flat. Exothermic combustion of methane into $\mathrm{H}_{2} \mathrm{O}$ and $\mathrm{CO}_{2}$ took place at the front edge of the plate, while endothermic reactions of methane steam and dry reforming occurred on the remaining part of the plate, yielding $\mathrm{CO}$ and $\mathrm{H}_{2}$. One microchannel plate demonstrated methane conversion of $82 \%$ and CO selectivity of $60 \%$ at a GHSV of $820,000 \mathrm{~h}^{-1}$ and under thermocycling of up to $900^{\circ} \mathrm{C}$. It was concluded that hydrogen production is proportional to the number of microchannel plates.

Other than attempts in meeting the objective to improve hydrogen yield, there have also been other engineered solutions to study POX presented in the literature for energy efficiency. One of them is the modeling study of POX on a methane-steam blend in a flow reactor of a given length conducted by Starik et al. (2015). Hydrogen-rich syngas production was achieved through oxygen activation by electric discharge. This plasma-chemical method exhibited significant achievement in the ratio of energy returned to energy consumed.

Wang et al. (2015) presented a new concept to increase the efficiency level of syngas production from solid oxide $\mathrm{H}_{2} \mathrm{O} / \mathrm{CO}_{2}$ co-electrolysis that previously had been found to require high energy input. The introduced concept combined co-electrolysis with POX to efficiently generate syngas on both sides of the electrolyzer, hence, demonstrating lower electric input and cathodic co-electrolysis polarization resistance, as compared to conventional co-electrolysis.

In summary, efforts have been made in the subject of methane partial oxidation to meet the objectives of minimizing carbon formation, increasing yield and selectivity, and improving energy efficiency. Summarized in Table 3 are the initiatives put forward in the work on POX reviewed in this paper.

\subsubsection{ATR of methane}

The complete ATR includes exothermic POX, the WGSR and the endothermic SMR reaction. The major chemical reactions are as follows (Lee et al. 2005):

Methane steam reforming reaction:

$$
\mathrm{CH}_{4}+\mathrm{H}_{2} \mathrm{O} \leftrightarrow \mathrm{CO}+3 \mathrm{H}_{2}
$$

WGSR:

$$
\mathrm{CO}+\mathrm{H}_{2} \mathrm{O} \leftrightarrow \mathrm{CO}_{2}+\mathrm{H}_{2}
$$

Coupling of steam reforming and WGSR:

$$
\mathrm{CH}_{4}+2 \mathrm{H}_{2} \mathrm{O} \leftrightarrow \mathrm{CO}_{2}+4 \mathrm{H}_{2}
$$

Methane partial oxidation reaction:

$$
\begin{gathered}
\mathrm{CH}_{4}+0.5 \mathrm{O}_{2} \rightarrow \mathrm{CO}+2 \mathrm{H}_{2} \\
\mathrm{CH}_{4}+\mathrm{O}_{2} \rightarrow \mathrm{CO}_{2}+2 \mathrm{H}_{2}
\end{gathered}
$$

Methane complete oxidation reaction:

$$
\mathrm{CH}_{4}+2 \mathrm{O}_{2} \rightarrow \mathrm{CO}_{2}+2 \mathrm{H}_{2} \mathrm{O}
$$

Yan et al. (2013) presented the study on characteristics of methane ATR to generate hydrogen using a thermodynamic equilibrium constant method, developed by MATLAB programming. Their investigation results showed that reaction (7) is prone to reverse at low temperature. By manipulating the steam-methane and air-methane ratios, the inflection point temperature for the reaction to move forward was successfully identified.

Their findings give useful information on molar ratio regulation. For example, at a molar ratio of steam to methane fixed at 2, an increase in the air-methane molar ratio brought up the inflection point temperature. On the other hand, fixing the air-methane molar ratio at the value of 1 would maintain the inflection point temperature in the range of $700-800 \mathrm{~K}$. At temperature exceeding $1000 \mathrm{~K}$, an opposite result was observed where an increase in the airmethane molar ratio brought down the production level of hydrogen. The optimized parameters for easy occurrence of methane ATR were demonstrated at a temperature of $1000 \mathrm{~K}$, an air-methane molar ratio of 1 and a steammethane molar ratio of 2 . The result also led to the finding that selectivity of $\mathrm{H}_{2} / \mathrm{CO}$ can be manipulated by regulating the steam-methane molar ratio (Yan et al. 2013). The air-methane ratio is one of the parameters manipulated in the attempt to achieve better conversion in the secondary reformer unit in a typical ammonia plant (Al-dhfeery and Jassem 2012).

Further manipulation of variables to find the optimized condition was simulated by Yan et al. (2015) in ATR of methane in a microreactor, using CHEMKIN. The effects on methane conversion, carbon deposition and product yield were investigated by varying the temperature, oxygen-carbon ratio, steam-carbon ratio and catalyst activity density. The findings are useful for the development of a mobile fuel cell.

Nickel has been the active metal used in the catalytic investigations of methane ATR. A study on the effect of nickel content supported on a high specific surface area nanocrystalline $\mathrm{MgAl}_{2} \mathrm{O}_{4}$, on the catalytic activity was demonstrated by Mosayebi et al. (2012). The highest methane conversion was observed on $15 \% \mathrm{Ni} / \mathrm{MgAl}_{2} \mathrm{O}_{4}$ compared to other lower nickel loading amounts in all the 


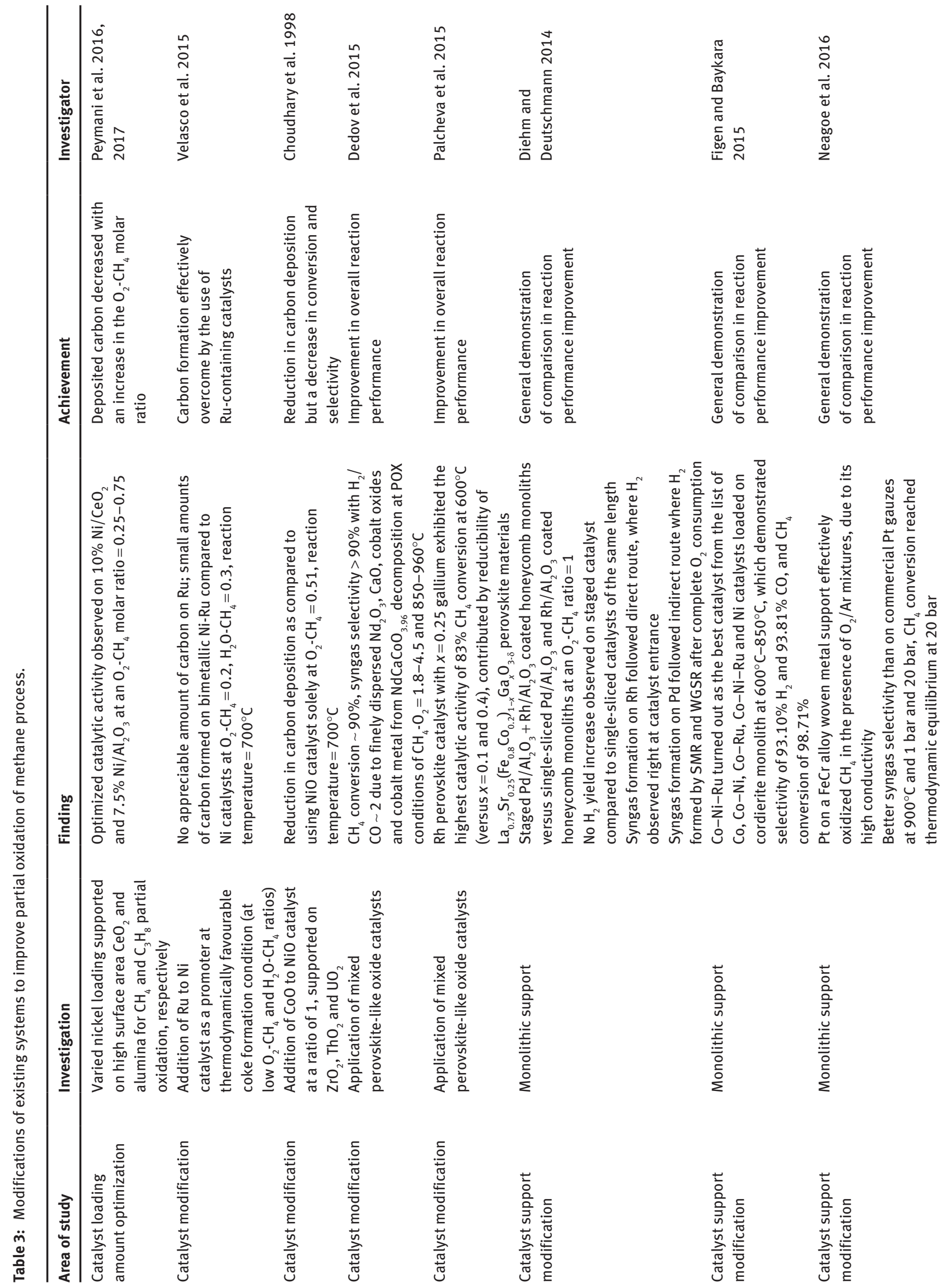




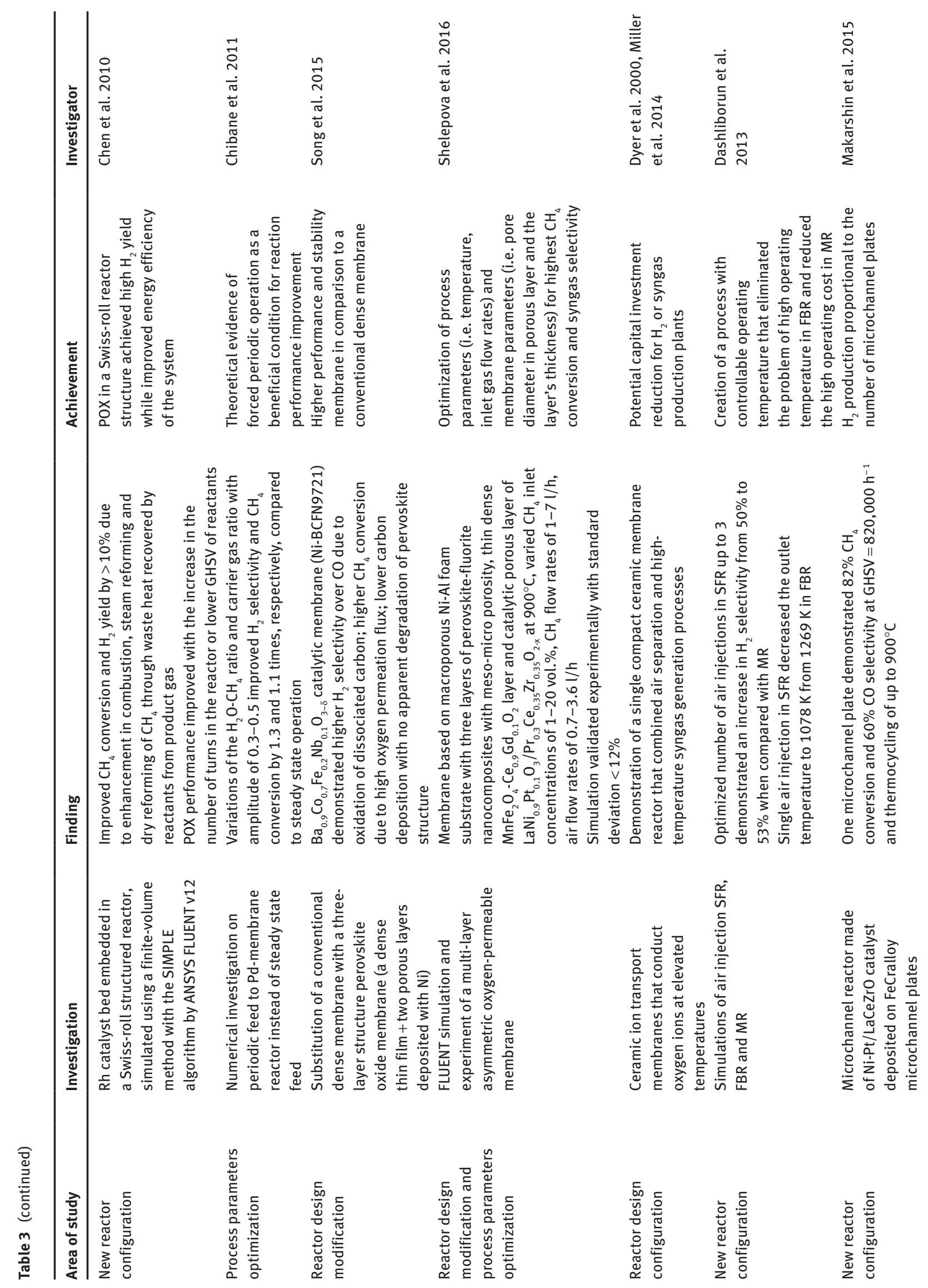




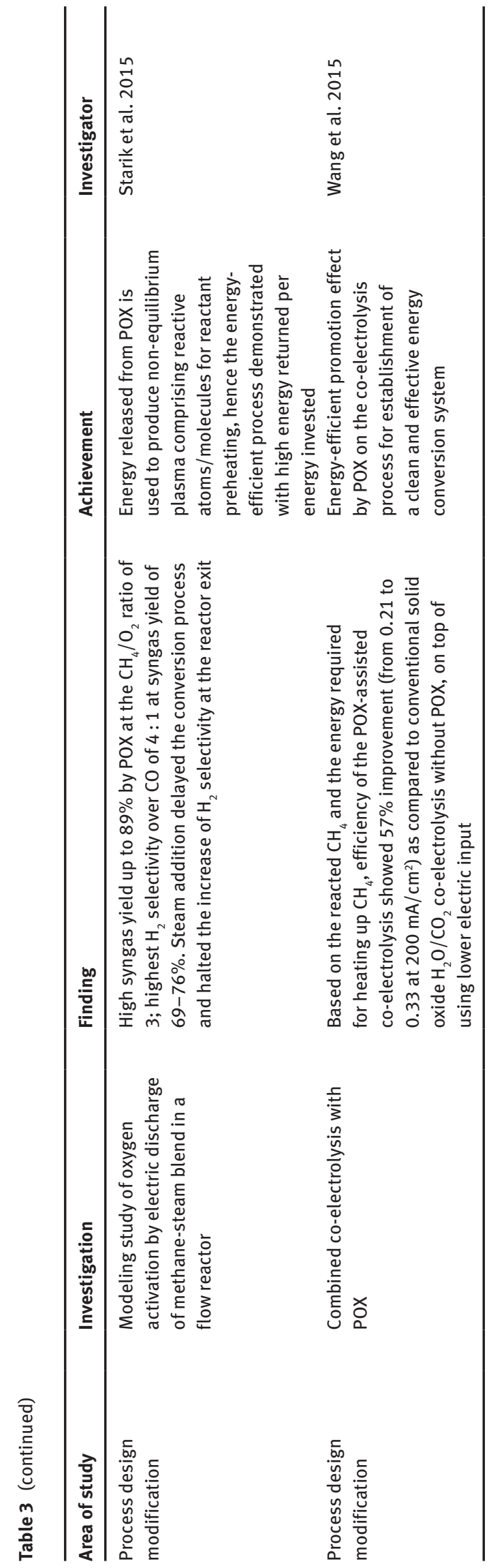

tested operation temperatures, while the catalysts maintained high stability during the time on stream. The study demonstrated that the feed ratio played a significant role on the catalytic activity where the increase in the oxygenmethane ratio up to 0.5 , and in the steam-methane ratio up to 1 , improved the methane conversion.

Catalytic investigations of ATR of methane have also included the use of bimetallic catalysts, where the second metal acts as a promoter to improve the structural and catalytic properties and hence enhance methane conversion and product yield and selectivity. A study by Sepehri et al. (2016) demonstrated the effect of adding small amounts $(\sim 3 \mathrm{wt} \%)$ of $\mathrm{La}, \mathrm{Ce}, \mathrm{Sr}$ and $\mathrm{Zr}$ as a promoter on the catalytic activity of nickel catalysts supported on $\gamma-\mathrm{Al}_{2} \mathrm{O}_{3}$ in ATR of methane. In general, the addition of the promoters investigated in this work resulted in high catalytic stability, without any formation of carbon on the catalyst surfaces. The addition of $\mathrm{Zr}$ helped improve the nickel catalyst reducibility, while the addition of $\mathrm{Sr}$, Ce and La promoted greater dispersion of nickel on $\gamma-\mathrm{Al}_{2} \mathrm{O}_{3}$, with Ce exhibiting the highest activity.

Ismagilov et al. (2014a) examined the effects of metal promoter type that included Pt, Pd, Re, Mo, Sn added to $\mathrm{Ni}$ supported on $\mathrm{La}_{2} \mathrm{O}_{3}$ at a varying promoter/Ni molar ratio of between 0.01 and 0.05 in the ATR of methane at low reaction temperatures of around $700-800^{\circ} \mathrm{C}$. A different promoter would impose a different level of impact on Ni species reducibility. At a promoter/Ni molar ratio of 0.01 , it was demonstrated that the order of promoters that increase methane conversion and product $\left(\mathrm{H}_{2}, \mathrm{CO}\right)$ selectivity was arranged in the manner of $\mathrm{Pt}<\mathrm{Sn}<\mathrm{Mo}<\operatorname{Re}<\mathrm{Pd}$.

On the basis of the above result, Ismagilov et al. (2014b) expanded their investigation by studying the influence of $\mathrm{Ce}_{0.5} \mathrm{Zr}_{0.5} \mathrm{O}_{2}$ and $\mathrm{La}_{2} \mathrm{O}_{3}$ additives on the physicochemical properties of Ni-Pd catalysts supported on alumina, using different catalyst preparation techniques, incipient wetness co-impregnation and sequential impregnation. The performance difference between Ni-Pd/Ce $\mathrm{Zr}_{0.5} \mathrm{O}_{2} /$ $\mathrm{Al}_{2} \mathrm{O}_{3}$ and $\mathrm{Ni}-\mathrm{Pd} / \mathrm{La}_{2} \mathrm{O}_{3} / \mathrm{Ce}_{0.5} \mathrm{Zr}_{0.5} \mathrm{O}_{2} / \mathrm{Al}_{2} \mathrm{O}_{3}$ was analyzed, and the best methane ATR performance was exhibited by $10 \mathrm{Ni}_{0.5} \mathrm{Pd} / 10 \mathrm{Ce}_{0.5} \mathrm{Zr}_{0.5} \mathrm{O}_{2} / \mathrm{Al}_{2} \mathrm{O}_{3}$, with Ni-Pd catalysts prepared by the sequential impregnation technique. It was concluded that different support compositions have a different degree of Ni-support interaction, and hence contribute to the homogeneity and uniformity of $\mathrm{NiO}$ catalyst dispersion, and Ni species reduction ability.

Researchers have also expanded the horizon of possible performance improvement in ATR through modification in a catalyst support substrate. The performance comparison between two substrates, structured ceramic 
honeycomb monolith and open cell foams, supporting $\mathrm{Ni}$ catalyst in methane ATR was done by Ciambelli et al. (2010). The reactor was integrated with a heat exchanger to exchange the heat from the exhaust stream to the inlet water and air streams in order to establish a process that was totally self-sustainable in the compact system. The steam-methane ratio was fixed at 0.49 and the GHSV was kept constant at $12,300 \mathrm{~h}^{-1}$, while the oxygen-methane ratio was varied between 0.56 and 0.75 . Foam structured catalyst exhibited higher activity (Ciambelli et al. 2010). A subsequent study (Palma et al. 2012) demonstrated equally good thermal conductivity and low average temperature with uniform temperature profile at the axial length of the catalytic bed in both monolithic support systems. Whilst this finding is promising toward commercialization of the foam-supported catalyst as a fuel cell, further investigation work at higher space velocity is still required since further analysis by Palma et al. (2012) revealed that only the first zone of the catalytic volume in the reactor bed was exploited, based on the analysis of temperature and gas composition along the bed length.

Table 4 summarizes the knowledge and information gained on ways to enhance reaction performance from the work performed by the researchers on the ATR, as reviewed in this paper.

\subsubsection{Methane decomposition}

Catalytic decomposition (or cracking) of methane offers potential route to production of high purity hydrogen, due to elimination of the water-gas shift reaction in the process, hence, removing the requirement for $\mathrm{CO}_{2}$ abstraction stages. This gives a direct impact on carbon credit (Mondal and Chandran 2014). A further purification step is not required for the COx-free hydrogen produced by thermocatalytic decomposition, and hence can directly be used as the fuel in $\mathrm{H}_{2}-\mathrm{O}_{2}$ fuel cell and internal combustion engine. This laboratory-level technology requires further intensive research and development before it can be scaled up to the industrial scale (Ashik et al. 2015).

In addition, the decomposition process produces carbon nanostructure as co-product, a novel nanomaterial that offers properties such as good mechanical strength, high surface area and great thermal conductivity, desired for applications as gas storage, additives in polymer, support for catalyst or the catalyst itself, to name a few (Teo et al. 2003, Ashik et al. 2015).

The reaction mechanism involves following five steps as described by Ashik et al. (2015): (i) Chemisorption of methane on the leading (frontexposed) face of a catalyst particle.

(ii) Detachment of a chemisorbed methane molecule through breaking of $\mathrm{C}-\mathrm{H}$ bonds:

$$
\left(\mathrm{CH}_{4}\right)_{\mathrm{g}} \rightarrow\left(\mathrm{CH}_{3}\right)_{\mathrm{a}}+(\mathrm{H})_{\mathrm{a}}
$$

followed by the release of elemental carbon and hydrogen through a series of surface stepwise dissociation reactions:

$$
\left(\mathrm{CH}_{3-x}\right)_{\mathrm{a}} \rightarrow\left(\mathrm{CH}_{2-x}\right)_{\mathrm{a}}+(\mathrm{H})_{\mathrm{a}}
$$

where $0<x<2$; subscripts (a) and (g) symbolize adsorbed and gaseous species, respectively.

(iii) Adsorption of atomic hydrogen aggregation into molecules, followed by emission of gas phase:

$$
(\mathrm{H})_{\mathrm{a}} \rightarrow\left(\mathrm{H}_{2}\right)_{\mathrm{g}}
$$

(iv) Aggregation of atomic carbon into encapsulated carbon by concentration difference, which leads to atomic carbon diffusion through the catalyst particle.

(v) Nucleation of carbon and subsequent growth of carbon filament in the trailing face of the catalyst particle:

$$
(\mathrm{C})_{\mathrm{a}} \rightarrow 1 / n\left(\mathrm{C}_{n}\right)_{\mathrm{c}}
$$

where subscript (c) denotes crystalline species.

This mechanism is derived based on the growth model postulated by Baker (1989) (Figure 6), which has become the most commonly accepted mechanism (Teo et al. 2003) for explaining CNF growth by catalytic decomposition of hydrocarbon. The model was proposed based on the synthesis of CNFs for various potential applications, which is a separate subject of interest.

Ideas in terms of process design have been evaluated to address the challenge in separating the carbon nanostructure deposited on the catalyst during the decomposition process, from the catalyst surface, in a continuous mode. This challenging requirement to separate carbon from the catalyst surface has the potential to be overcome based on the findings in a simulated study conducted by Mondal and Chandran (2014). The investigation explored low-temperature hydrogen production from a stepwise cyclic process of thermo-catalytic decomposition of methane $\left(\mathrm{CH}_{4} \rightarrow 2 \mathrm{H}_{2}+\mathrm{C}\right)$, followed by gasification by steam $\left(\mathrm{C}+2 \mathrm{H}_{2} \mathrm{O} \rightarrow 2 \mathrm{H}_{2}+\mathrm{CO}_{2}\right)$ at the same temperature. In addition, this stepwise cyclic process produced hydrogen slightly higher than that from the conventional steam reforming process for every mole of methane, on top of operating at much lower temperature $\left(600^{\circ} \mathrm{C}\right)$, hence saving significant energy. In the cyclic process, the re-oxidation of the metal catalysts took place in the 


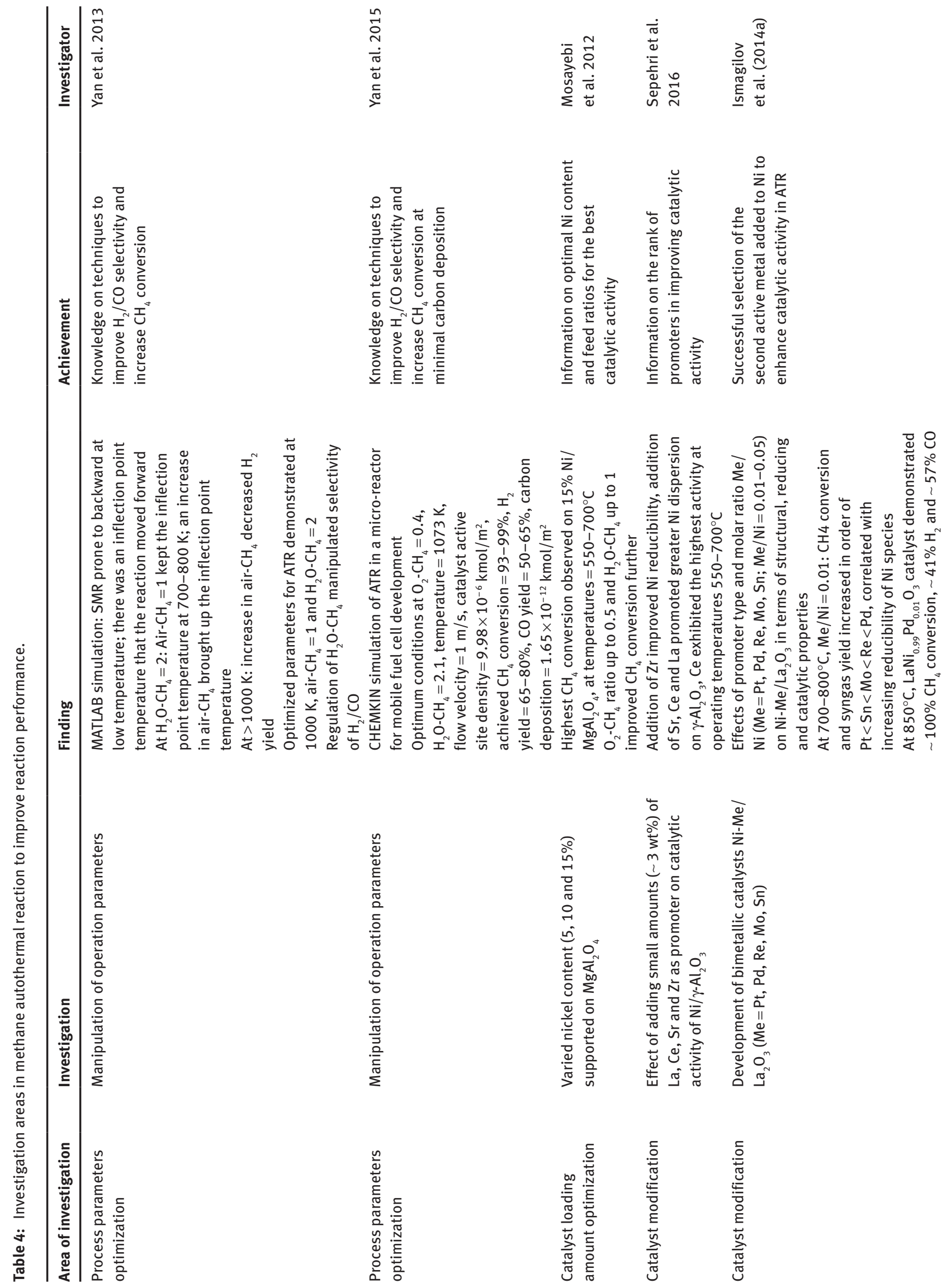




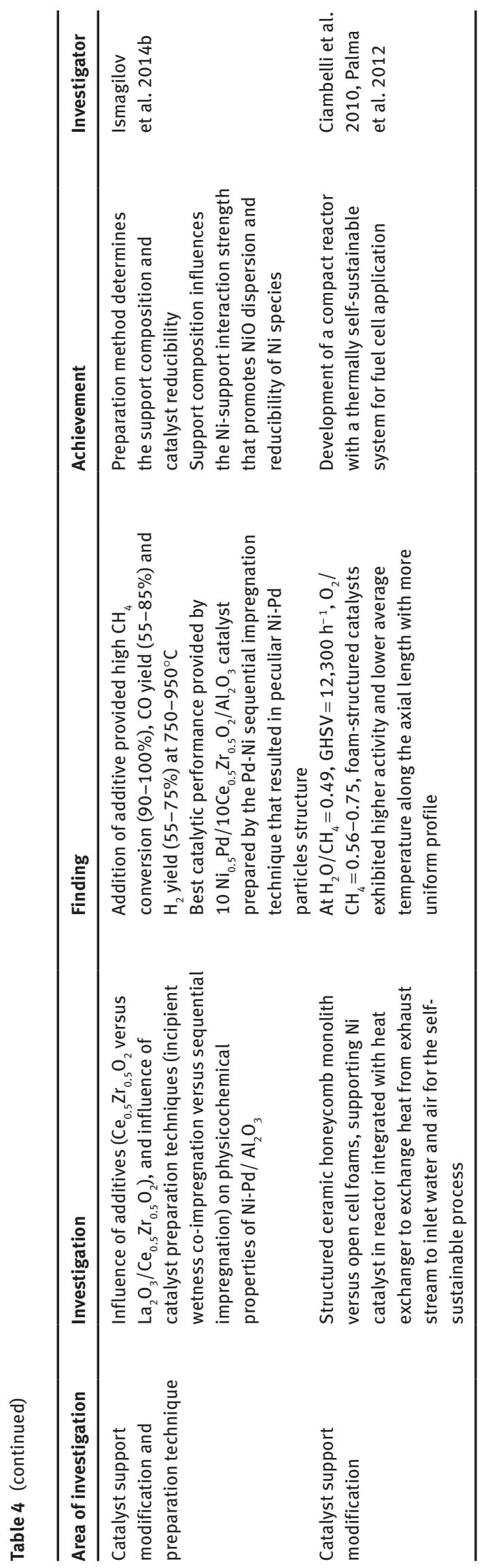

regeneration step and then the particle was re-reduced in $\mathrm{H}_{2}$ for reactivation, and the methane decomposition step repeated accordingly.

Methane is one of the most inactive hydrocarbons that has very strong carbon-hydrogen bond and high symmetrical molecular structure. In the absence of a catalyst, its efficient decomposition could only occur at temperatures beyond $1200^{\circ} \mathrm{C}$ in order to break the strong carbon-hydrogen bond $(440 \mathrm{~kJ} / \mathrm{mol})$ due to its high thermodynamic stability. There have been various studies conducted in the attempt to bring down this temperature through utilization of metal and carbon-derived catalysts (Ashik et al. 2015). A large amount of amorphous carbon is formed during this endothermic reaction that leads to catalyst deactivation. Various studies have been carried out to overcome this issue, through modifications of transitional metals, rare earth (RE) metals, alloys and carbon material catalysts.

Bayat et al. (2016b) presented a catalytic performance study on thermocatalytic decomposition of methane using varied nickel catalyst loading amounts on mesoporous nanocrystalline $\gamma-\mathrm{Al}_{2} \mathrm{O}_{3}$ support. The level of catalytic activity changed with the variation in nickel content, whereas the stability of the catalysts was dependent on the reaction temperature. Nickel content at $50 \mathrm{wt} \%$ demonstrated the highest catalyst's activity and stability at reaction temperatures of $625^{\circ} \mathrm{C}$ and $650^{\circ} \mathrm{C}$, but the reaction rates increased and accelerated the catalyst deactivation when the reaction was run at higher operating temperatures. It was also noted that an operation at lower temperatures decreased the methane conversion. The morphology of the used catalysts from scanning electron microscopy analysis revealed formation of CNFs with diameter close to the nickel particle size, but the diameter of the CNFs decreased with the increase in the operating temperature.

Transitional metals other than nickel have also been used in the methane decomposition performance studies. Ibrahim et al. (2015) investigated the activity performance by different iron loadings of $15-100 \%$ supported on alumina catalyst. It was revealed that hydrogen yield increased with higher iron loading up to $60 \%$ where loadings higher than this were found to have decreased the catalyst's surface area. At $700^{\circ} \mathrm{C}$, the yield of hydrogen over $60 \% \mathrm{Fe} / \mathrm{Al}_{2} \mathrm{O}_{3}$ catalyst was $77 \%$.

Investigation on the addition of a second transitional metal to the first has also been carried out. Bayat et al. (2016c) examined the catalytic behavior of iron added to nickel catalysts on $\gamma$-alumina support. Analysis conducted confirmed formation of $\mathrm{NiFe}_{2} \mathrm{O}_{4}$ species in calcined $\mathrm{Ni}-\mathrm{Fe}$ alloy catalysts, but the degree of reducibility reduced with increasing composition of iron in the alloy. However, the addition of iron improved the catalytic stability through 
enhancement of the carbon diffusion rate (step $\mathrm{C}$ in Figure 6) and prevention of carbon encapsulation that deactivates the catalyst at reaction temperatures of below $650^{\circ} \mathrm{C}$.

Bayat et al. (2016a) expanded the study by carrying out a catalytic performance investigation in methane decomposition using $50 \mathrm{wt} \% \mathrm{Ni}$ supported on alumina, with an addition of fixed Fe content of $10 \%$ and varied $\mathrm{Cu}$ contents of 0, 5, 10 and 15\%, as promoters. Although it was found that iron decreased the reducibility of the nickel catalyst, copper on the other hand compensated this effect by increasing the adsorption of methane while at the same time improving the dispersion of nickel particles on the support. It was revealed that the addition of both promoters resulted in an improvement in the catalytic performance, due to an enhancement of carbon diffusion rate that helped prevent coke formation on the nickel surface. Additionally, the high affinity of copper with a graphite structure contributed to further effect of coke formation prevention, which slowed down the catalyst deactivation at reaction temperatures of above $700^{\circ} \mathrm{C}$, with $50 \% \mathrm{Ni}-10 \% \mathrm{Fe}-10 \% \mathrm{Cu} / \mathrm{Al}_{2} \mathrm{O}_{3}$ displaying optimum catalytic performance.

In an earlier work, the catalytic behavior of Ni-Cu-containing catalyst particles was investigated to understand the effect of adding additional transitional metal. Different compositions of Ni-Cu-Co alloy catalysts prepared by Lua and Wang (2014) were observed to have resulted in porous aggregates of Ni-Cu-Co alloy particles of different

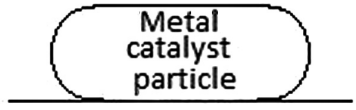

Support

A

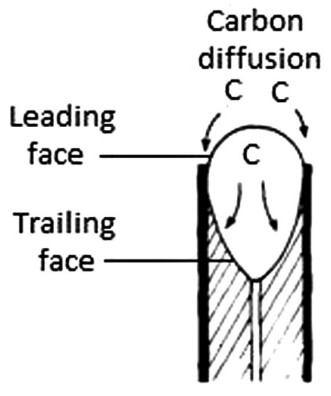

C

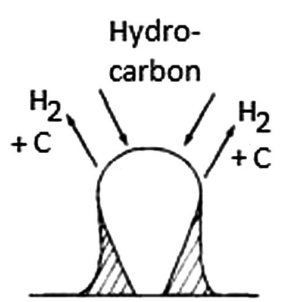

B

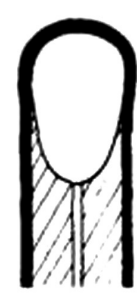

D
Figure 6: Growth mechanism of carbon nanofibers by catalytic hydrocarbon decomposition postulated by Baker (1989). crystalline sizes. Based on general observation on the trimetal alloy, good catalytic activities on methane decomposition were exhibited at temperatures between 650 and $775^{\circ} \mathrm{C}$. Due to higher melting point of cobalt, the addition of it resulted in effective inhibition of a quasi-liquid phenomenon at higher temperatures, and hence, improved catalysts stability, in comparison with the Ni-Cu bi-metallic alloy. However, a continued increase in cobalt content led to phase separation.

A study on the effect of cobalt content was also carried out by Awadallah and Aboul-Enein (2015) over bimetallic catalysts containing a series of $\mathrm{Co} / \mathrm{W}$ at $40 / 10,30 / 20$, 20/30 and $10 / 40 \mathrm{wt} \%$, supported on $\mathrm{MgO}$ with a total metal content of $50 \mathrm{wt} \%$. It was revealed that the $40 \% \mathrm{Co}-10 \% \mathrm{~W} /$ $\mathrm{MgO}$ catalyst exhibited the highest activity for the production of hydrogen as well as the carbon nanostructure (observed in the form of multi-walled carbon nanotubes in this study). Based on their analysis, this catalyst superiority achievement was attributed to the large amount formation of non-interacted $\mathrm{Co}_{3} \mathrm{O}_{4}$ species.

In general, a lot of other investigations in methane decomposition catalytic activity are focusing on the effect of adding the content of other metals on nickel-based catalyst. Ying et al. (2014) synthesized different RE-Ni bimetallic catalysts to evaluate the performance of methane decomposition in a fixed bed microreactor. The RE utilized in their study included La, Ce, Pr, Nd, Sm and Y, where it was demonstrated that the RE-modified nickel catalysts resulted in smaller nickel particle size, good thermal stability and high activity, on top of preventing solid carbon formation. Of all the REs, La was found to be the best additive in the examination.

Carbon materials have also been seen as promising catalysts for methane decomposition and hence serve as an alternative to expensive transition metals. Activated carbon (AC) is able to provide reasonable reaction kinetics for production of continuous high purity hydrogen, as investigated by Liu et al. (2016) through the application of a chemical looping process. No signs of deactivation and agglomeration of $\mathrm{AC}$ catalyst were observed during the cyclic study under proper regeneration, and $\mathrm{CO}_{2}$-free hydrogen of high purity was produced continuously. The application of AC catalyst is enabled by its crushing strength, and hence, it is suitable for a chemical looping process.

Shen and Lua (2016) presented methods to synthesize porous carbon of an interconnected trimodal pore system as the catalyst for decomposition of methane. The trimodal pore system that was synthesized consisted of intra-mesopores and micropores that provided a large surface area for reactant accessibility to active sites and 


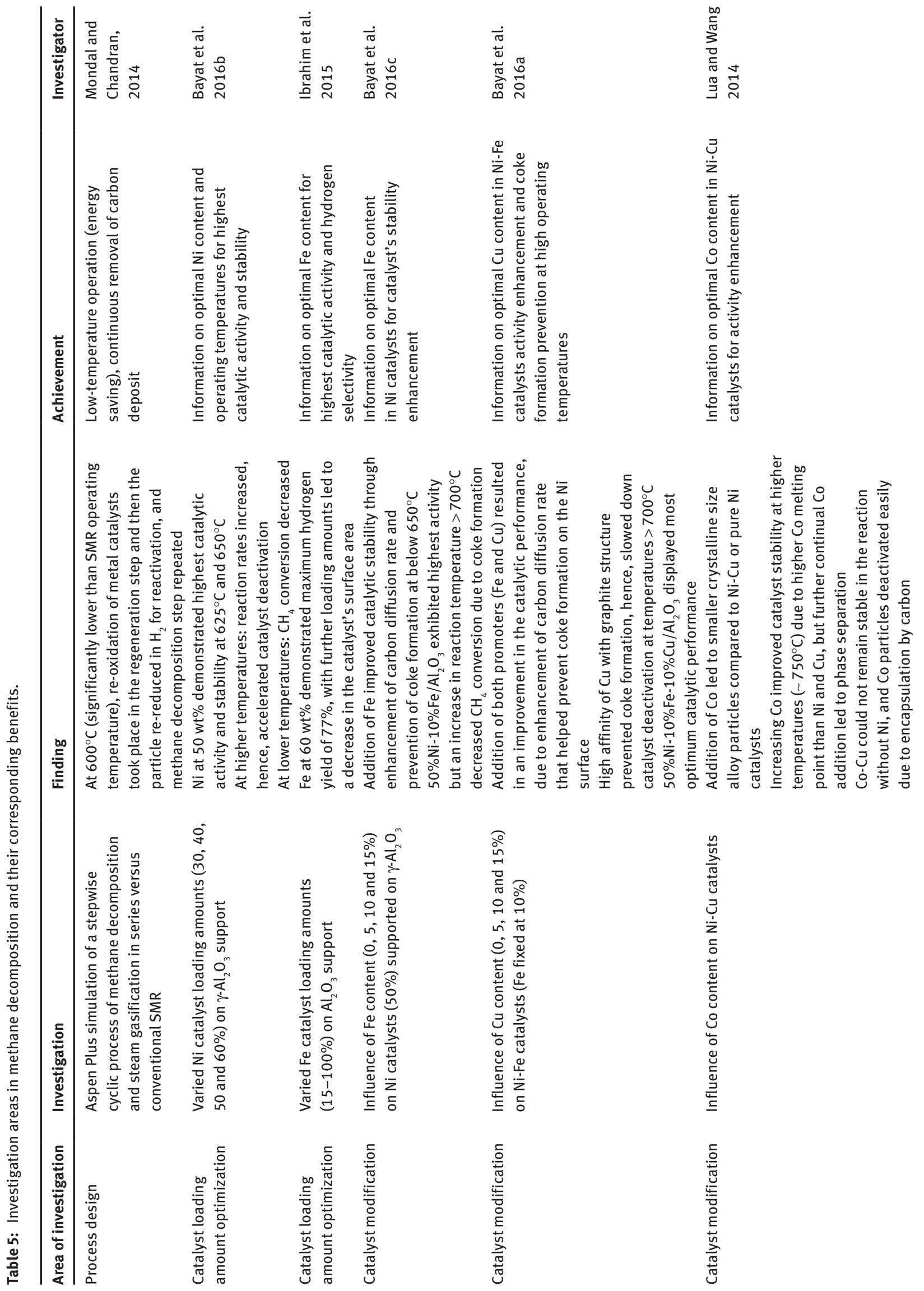




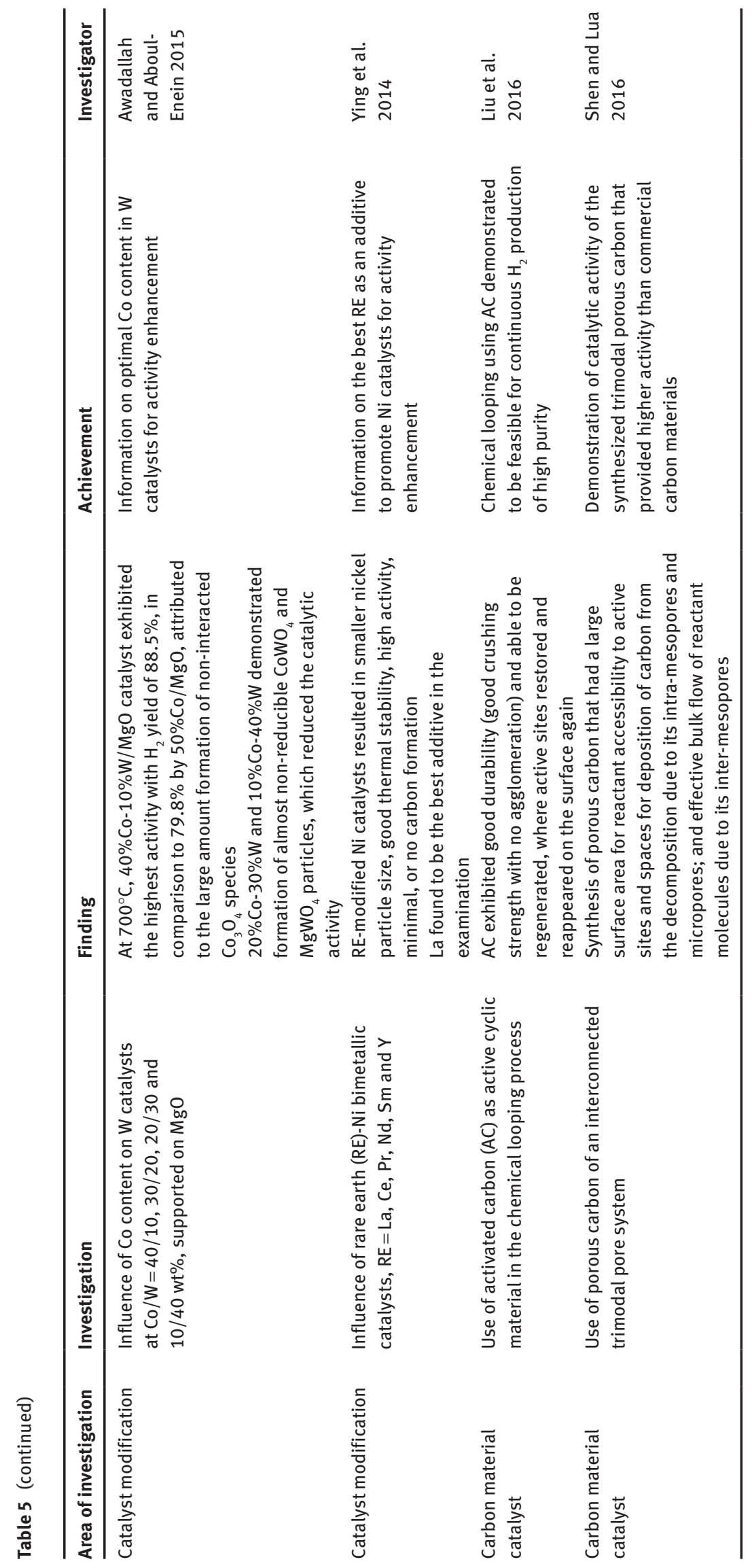


spaces for deposition of carbon from the decomposition, and inter-mesopores for effective bulk flow of the reactant molecules, and hence, minimized reactant's diffusion resistance. Higher methane conversion and hydrogen yield were achieved with as-synthesized carbon in this study compared to the commercial carbon materials.

Table 5 provides summarized findings on efforts taken in improving methane decomposition in terms of conversion efficiency, carbon deposition minimization, hydrogen purification as well as energy saving through low-temperature operation as reviewed in this paper.

\section{Conclusions}

Hydrogen finds applications in a large production scale at chemical plants and oil refineries, as a raw material for the synthesis of mainly ammonia and methanol, and as reactant in hydrocracking and hydrofining of oil to produce transportation fuels and remove contaminants such as sulfur to meet the emission legislation and fuel specifications. At a smaller scale where hydrogen is being generated from renewable energy sources like wind and solar energy that power the water electrolysis process, hydrogen finds its applications as an energy carrier being stored on electricity grids, and as fuel in hydrogen vehicles, used in internal combustion engines and fuel cells, and hence, reduces the reliance on fossil fuels and the emissions of greenhouse gas.

The main routes of hydrogen production at a large scale for industrial utilization are widely coming from thermocatalytic processing of methane, the main component in natural gas, which accounts for close to half of the total hydrogen production resource. The same technologies are also applicable to process petroleum oil components such as naphtha, which accounts for slightly less than a third of the total resource. Whilst methane decomposition or cracking technology is still at the laboratory scale level and has yet to find its place on an industrial scale, SMR dominates the hydrogen production technology, along with two other most commonly used catalytic hydrocarbon processing technologies: POX and ATR. These three technologies are the most economical and efficient for large-scale hydrogen production.

In all the technologies reviewed, a lot of interest has been developed among researchers to introduce initiatives in improving methane conversion, hydrogen selectivity and energy efficiency as well as suppressing coke formation that accelerates catalyst deactivation. Among the general efforts identified from the review include studies on qualifying various oxygen-transfer materials as the catalyst support; addition of the second and third metals to the primary metal catalyst, or addition of mixed perovskite-like oxides to the primary support material to act as promoters; the use of monolithic catalytic support to replace the pelletized catalytic system; reactor configuration modifications; and engineering process modifications.

Acknowledgments: We acknowledge the financial support of the Department of Chemical and Process Engineering, University of Canterbury.

\section{References}

Al-dhfeery AA, Jassem AA. Modeling and simulation of an industrial secondary reformer reactor in the fertilizer plants. Int J Ind Chem 2012; 3: 1-8.

Ally J, Pryor T, Pigneri A. The role of hydrogen in Australia's transport energy mix. Int J Hydrogen Energy 2015; 40: 4426-4441.

Andrews J, Shabani B. Re-envisioning the role of hydrogen in a sustainable energy economy. Int J Hydrogen Energy 2012; 37 : 1184-1203.

Antzara A, Heracleous E, Silvester L, Bukur DB, Lemonidou AA. Activity study of NiO-based oxygen carriers in chemical looping steam methane reforming. Catal Today 2016; 272: 32-41.

Apak S, Atay E, Tuncer G. Renewable hydrogen energy regulations, codes and standards: challenges faced by an EU candidate country. Int J Hydrogen Energy 2012; 37: 5481-5497.

Ashik U, Daud WW, Abbas HF. Production of greenhouse gas free hydrogen by thermocatalytic decomposition of methane - a review. Renew Sustainable Energy Rev 2015; 44: 221-256.

Awadallah AE, Aboul-Enein AA. Catalytic decomposition of methane to COx-free hydrogen and carbon nanotubes over $\mathrm{Co}-\mathrm{W} / \mathrm{MgO}$ catalysts. Egypt J Pet 2015; 24: 299-306.

Baker RTK. Catalytic growth of carbon filaments. Carbon 1989; 27 : 315-323.

Barreto L, Makihira A, Riahi K. Medium and long-term demand and supply prospects for fuel cells: the hydrogen economy and perspectives for the 21st century. International Institute for Applied Systems Analysis, Laxenburg, 2002.

Barreto L, Makihira A, Riahi K. The hydrogen economy in the 21st century: a sustainable development scenario. Int J Hydrogen Energy 2003; 28: 267-284.

Bayat N, Meshkani F, Rezaei M. Thermocatalytic decomposition of methane to $\mathrm{COx}$-free hydrogen and carbon over $\mathrm{Ni}-\mathrm{Fe}-\mathrm{Cu} / \mathrm{Al}_{2} \mathrm{O}_{3}$ catalysts. Int J Hydrogen Energy 2016a; 41: 13039-13049.

Bayat N, Rezaei M, Meshkani F. COx-free hydrogen and carbon nanofibers production by methane decomposition over nickel-alumina catalysts. Korean J Chem Eng 2016b; 33: 490-499.

Bayat N, Rezaei M, Meshkani F. Methane decomposition over Ni-Fe/ $\mathrm{Al}_{2} \mathrm{O}_{3}$ catalysts for production of $\mathrm{COx}$-free hydrogen and carbon nanofiber. Int J Hydrogen Energy 2016c; 41: 1574-1584.

Board on Energy and Environmental Systems National Research Council, Division on Engineering and Physical Sciences National Research Council, Washington National Academy of 
Engineering. The hydrogen economy: Opportunities, costs, barriers, and R\&D needs. Washington: National Academies Press, 2004.

Castaneda L, Munoz J, Ancheyta J. Comparison of approaches to determine hydrogen consumption during catalytic hydrotreating of oil fractions. Fuel 2011; 90: 3593-3601.

Cecere D, Giacomazzi E, Ingenito A. A review on hydrogen industrial aerospace applications. Int J Hydrogen Energy 2014; 39: 10731-10747.

Chen W-H, Chiu T-W, Hung C-I. Enhancement effect of heat recovery on hydrogen production from catalytic partial oxidation of methane. Int J Hydrogen Energy 2010; 35: 7427-7440.

Chernyi YP, Feigin S. Hydrogen consumption and the technological scheme of crude refining. Chem Tech Fuels Oil 1968; 4: 661-663.

Chibane L, Djellouli B, Benguerba Y. Forced composition cycling of a Pd-membrane reactor for pure hydrogen production from the reaction of partial oxidation of methane. Chem Eng J 2011; 178: 398-406.

Chilcott RP. Phosgene general information. Oxfordshire, UK: Health Protection Agency (HPA), Chemical Hazards and Poisons Division, 2007.

Choi DH, Chun SM, Ma SH, HongYC. Production of hydrogen-rich syngas from methane reforming by steam microwave plasma. J Ind Eng Chem 2016; 34: 286-291.

Choudhary V, Rajput A, Prabhakar B, Mamman A. Partial oxidation of methane to $\mathrm{CO}$ and $\mathrm{H}_{2}$ over nickel and/or cobalt containing $\mathrm{ZrO}_{2}, \mathrm{ThO}_{2}, \mathrm{UO}_{2}, \mathrm{TiO}_{2}$ and $\mathrm{SiO}_{2}$ catalysts. Fuel 1998; 77: 1803-1807.

Ciambelli P, Palma V, Palo E. Comparison of ceramic honeycomb monolith and foam as $\mathrm{Ni}$ catalyst carrier for methane autothermal reforming. Catal Today 2010; 155: 92-100.

Ciambelli P, Palma V, Iaquaniello G, Palo E. Autothermal reforming case study. In: De Falco M, Marrelli L, laquaniello G, editors. Membrane reactors for hydrogen production processes. London: Springer, 2011: 123-142.

Conte M, lacobazzi A, Ronchetti M, Vellone R. Hydrogen economy for a sustainable development: state-of-the-art and technological perspectives. J Power Sources 2001; 100; 171-187.

Dahiya RP, Chand A. Utilisation of hydrogen for domestic, commercial and industrial applications. In: Dahiya RP, editor. Progress in hydrogen energy. Netherlands: Springer, 1987: 179-194.

Dashliborun AM, Fatemi S, Najafabadi AT. Hydrogen production through partial oxidation of methane in a new reactor configuration. Int J Hydrogen Energy 2013; 38: 1901-1909.

Dedov A, Loktev A, Komissarenko D, Mazo G, Shlyakhtin 0, Parkhomenko K, Kiennemann AA, Roger A-C, Ishmurzin AV, Moiseev, II. Partial oxidation of methane to produce syngas over a neodymium-calcium cobaltate-based catalyst. Appl Catal A 2015; 489: 140-146.

Diehm C, Deutschmann 0. Hydrogen production by catalytic partial oxidation of methane over staged $\mathrm{Pd} / \mathrm{Rh}$ coated monoliths: spatially resolved concentration and temperature profiles. Int J Hydrogen Energy 2014; 39: 17998-18004.

Dincer I. Technical, environmental and exergetic aspects of hydrogen energy systems. Int J Hydrogen Energy 2002; 27: 265-285.

Dry ME. High quality diesel via the Fischer-Tropsch process - a review. J Chem Technol Biotechnol 2002; 77: 43-50.

Đukanović Z, Glišić SB, Čobanin VJ, Nićiforović M, Georgiou CA, Orlović AM. Hydrotreating of straight-run gas oil blended with
FCC naphtha and light cycle oil. Fuel Process Technol 2013; 106: 160-165.

Dyer PN, Richards RE, Russek SL, Taylor DM. Ion transport membrane technology for oxygen separation and syngas production. Solid State Ionics 2000; 134: 21-33.

Elgowainy A, Gaines L, Wang M. Fuel-cycle analysis of early market applications of fuel cells: forklift propulsion systems and distributed power generation. Int J Hydrogen Energy 2009; 34: 3557-3570.

Erisman JW, Sutton MA, Galloway J, Klimont Z, Winiwarter W. How a century of ammonia synthesis changed the world. Nat Geosci 2008; 1: 636-639.

Ewan B, Allen R. A figure of merit assessment of the routes to hydrogen. Int J Hydrogen Energy 2005; 30: 809-819.

Figen HE, Baykara SZ. Hydrogen production by partial oxidation of methane over Co based, $\mathrm{Ni}$ and Ru monolithic catalysts. Int J Hydrogen Energy 2015; 40: 7439-7451.

Fogler H. Scott elements of chemical reaction engineering, $3 \mathrm{rd}$ ed. London: Prentice Hall PTR and Upper Saddle River, NJ: Prentice-Hall, 1999.

Gaudernack B. Hydrogen production from fossil fuels. In: Saetre TO, editor. Hydrogen power: theoretical and engineering solutions. Netherlands: Springer, 1998: 75-89.

Giroux T, Hwang S, Liu Y, Ruettinger W, Shore L. Monolithic structures as alternatives to particulate catalysts for the reforming of hydrocarbons for hydrogen generation. Appl Catal B 2005; 56: 95-110.

Heck RM, Gulati S, Farrauto RJ. The application of monoliths for gas phase catalytic reactions. Chem Eng J 2001; 82: 149-156.

Hewu W, Haiyan H, Xue D, Minggao O. Hydrogen and fuel-cell vehicle technology. In: Sustainable automotive energy system in China. Berlin Heidelberg: Springer, 2013: 301-333.

Holladay JD, Hu J, King DL, Wang Y. An overview of hydrogen production technologies. Catal Today 2009; 139: 244-260.

Holt M, Glover C. Energy policy act of 2005: summary and analysis of enacted provisions. Congressional Research Service, USA: Library of Congress, 2006.

Hosseini SE, Wahid MA. Hydrogen production from renewable and sustainable energy resources: promising green energy carrier for clean development. Renew Sustainable Energy Rev 2016; 57: 850-866.

Hudson MSL, Dubey P, Pukazhselvan D, Pandey SK, Singh RK, Raghubanshi H, Shahi RR, Srivastava ON. Hydrogen energy in changing environmental scenario: Indian context. Int J Hydrogen Energy 2009; 34: 7358-7367.

Ibrahim AA, Fakeeha AH, Al-Fatesh AS, Abasaeed AE, Khan WU. Methane decomposition over iron catalyst for hydrogen production. Int J Hydrogen Energy 2015; 40: 7593-7600.

Ismagilov IZ, Matus EV, Kuznetsov VV, Mota N, Navarro RM, Yashnik SA, Prosvirin IP, Kerzhentsev MA, Ismagilov ZR, Fierro JLG. Hydrogen production by autothermal reforming of methane: effect of promoters (Pt, Pd, Re, Mo, Sn) on the performance of $\mathrm{Ni} / \mathrm{La}_{2} \mathrm{O}_{3}$ catalysts. Appl Catal A 2014a; 481: 104-115.

Ismagilov I, Matus E, Kuznetsov V, Kerzhentsev M, Yashnik S, Prosvirin I, Mota N, Navarro RM, Fierro JLG, Ismagilov ZR. Hydrogen production by autothermal reforming of methane over NiPd catalysts: effect of support composition and preparation mode. Int J Hydrogen Energy 2014b; 39: 2099221006. 
Jones G, Jakobsen JG, Shim SS, Kleis J, Andersson MP, Rossmeisl J, Abild-Pedersen F, Bligaard T, Helveg S, Hinnemann B, RostrupNielsen JR, Chorkendorff Ib, Sehested J, Nørskov JK. First principles calculations and experimental insight into methane steam reforming over transition metal catalysts. J Catal 2008; 259: $147-160$.

Kho ET, Scott J, Amal R. Ni/TiO for low temperature steam reforming of methane. Chem Eng Sci 2016; 140: 161-170.

Kim TW, Park JC, Lim T-H, Jung H, Chun DH, Lee HT, Hong S, Yang $\mathrm{J}-\mathrm{I}$. The kinetics of steam methane reforming over a $\mathrm{Ni} / \gamma-\mathrm{Al}_{2} \mathrm{O}_{3}$ catalyst for the development of small stationary reformers. Int J Hydrogen Energy 2015; 40: 4512-4518.

Kobl K, Thomas S, Zimmermann Y, Parkhomenko K, Roger A-C. Power-law kinetics of methanol synthesis from carbon dioxide and hydrogen on copper-zinc oxide catalysts with alumina or zirconia supports. Catal Today 2016; 270: 31-42.

Kraleva E, Pohl M-M, Jürgensen A, Ehrich $\mathrm{H}$. Hydrogen production by bioethanol partial oxidation over Ni based catalysts. Appl Catal B 2015; 179: 509-520.

Krumdieck S, Dantas A. The visioning project: part of the transition engineering process. 3rd International Conference on Sustainability Engineering and Science, Auckland, 2008.

Kyriakou V, Garagounis I, Vourros A, Vasileiou E, Manerbino A, Coors WG, Stoukides M. Methane steam reforming at low temperatures in a $\mathrm{BaZr}_{0.7} \mathrm{Ce}_{0.2} \mathrm{Y}_{0.1} \mathrm{O}_{2.9}$ proton conducting membrane reactor. Appl Catal B 2016; 186: 1-9.

Lee SH, Applegate DV, Ahmed S, Calderone SG, Harvey TL. Hydrogen from natural gas: part I - autothermal reforming in an integrated fuel processor. Int J Hydrogen Energy 2005; 30: 829-842.

LeValley TL, Richard AR, Fan M. Development of catalysts for hydrogen production through the integration of steam reforming of methane and high temperature water gas shift. Energy 2015; 90: 748-758.

Lin Z, Dong J, Greene DL. Hydrogen vehicles: impacts of DOE technical targets on market acceptance and societal benefits. Int J Hydrogen Energy 2013; 38: 7973-7985.

Liu F, Chen L, Yang L, Fan Z, Nikolic H, Richburg L, Liu K. Application of chemical looping process for continuous high purity hydrogen production by methane thermocatalytic decomposition. Int J Hydrogen Energy 2016; 41: 4592-4602.

Lokey E. A critical review of the Energy Policy Act of 2005's treatment of hydrogen. Int J Hydrogen Energy 2007; 32: 1673-1679.

Lua AC, Wang HY. Hydrogen production by catalytic decomposition of methane over Ni-Cu-Co alloy particles. Appl Catal B 2014; 156: 84-93.

Makarshin LL, Sadykov VA, Andreev DV, Gribovskii AG, Privezentsev VV, Parmon VN. Syngas production by partial oxidation of methane in a microchannel reactor over a Ni-Pt/La $\mathrm{Lr}_{0.2} \mathrm{Zr}_{0.4} \mathrm{Ce}_{0.4} \mathrm{O}_{x}$ catalyst. Fuel Process Technol 2015; 131: 21-28.

Marshall A, Børresen B, Hagen G, Tsypkin M, Tunold R. Hydrogen production by advanced proton exchange membrane (PEM) water electrolysers - reduced energy consumption by improved electrocatalysis. Energy 2007; 32: 431-436.

Martínez J, Ancheyta J. Modeling the kinetics of parallel thermal and catalytic hydrotreating of heavy oil. Fuel 2014; 138: 27-36.

Mellsop SR, Gardiner A, Marshall AT. Electrocatalytic oxygen evolution on electrochemically deposited cobalt oxide films: comparison with thermally deposited films and effect of thermal treatment. Electrocatalysis 2014; 5: 445-455.
Miller C, Chen J, Carolan M, Foster E. Advances in ion transport membrane technology for Syngas production. Catal Today 2014; 228: 152-157.

Mondal KC, Chandran SR. Evaluation of the economic impact of hydrogen production by methane decomposition with steam reforming of methane process. Int J Hydrogen Energy 2014; 39: 9670-9674.

Mosayebi Z, Rezaei M, Ravandi AB, Hadian N. Autothermal reforming of methane over nickel catalysts supported on nanocrystalline $\mathrm{MgAl}_{2} \mathrm{O}_{4}$ with high surface area. Int J Hydrogen Energy 2012; 37 : 1236-1242.

Muradov N. Hydrogen from fossil fuels without $\mathrm{CO}_{2}$ emissions. In: Grégoire Padró CE, Lau F, editors. Advances in hydrogen energy. USA: Springer, 2002: 1-16.

Navarro R, Pena M, Fierro J. Hydrogen production reactions from carbon feedstocks: fossil fuels and biomass. Chem Rev 2007; 107: 3952-3991.

Neagoe C, Boffito DC, Ma Z, Trevisanut C, Patience GS. Pt on FeCralloy catalyses methane partial oxidation to syngas at high pressure. Catal Today 2016; 270: 43-50.

Nitsch J, Voigt C. Hydrogen's potential. In: Winter C-J, Nitsch J, editors. Hydrogen as an energy carrier. Berlin Heidelberg: Springer, 1988: 293-313.

Novinson T. The ethyl biodiesel alternative. Biodiesel Magazine, 2004.

Paez DE, Andriollo A, Morfes G. Aqueous-phase catalytic hydrogenation and hydrogenolysis reactions of sulfur-and nitrogen-containing compounds in oil fractions. Catal Today 2015; 247: 139-146.

Palcheva R, Olsbye U, Palcut M, Rauwel P, Tyuliev G, Velinov $\mathrm{N}$, Fjellvåg $\mathrm{HH}$. Rh promoted $\mathrm{La}_{0.75} \mathrm{Sr}_{0.25}\left(\mathrm{Fe}_{0.8} \mathrm{Co}_{0.2}\right)_{1-x} \mathrm{Ga}_{x}$ $\mathrm{O}_{3-\delta}$ perovskite catalysts: characterization and catalytic performance for methane partial oxidation to synthesis gas. Appl Surf Sci 2015; 357(Part A): 45-54.

Palma V, Ricca A, Ciambelli P. Monolith and foam catalysts performances in ATR of liquid and gaseous fuels. Chem Eng J 2012; 207: 577-586.

Pang S, Li J. BIGCC system for New Zealand: an overview and perspective. New Zealand J Forest 2006; 51: 7-12.

Peymani M, Alavi SM, Rezaei M. Preparation of highly active and stable nanostructured $\mathrm{Ni} / \mathrm{CeO}_{2}$ catalysts for syngas production by partial oxidation of methane. Int J Hydrogen Energy 2016; 41: 6316-6325.

Peymani M, Alavi SM, Rezaei M. Synthesis gas production by catalytic partial oxidation of propane on mesoporous nanocrystalline $\mathrm{Ni} / \mathrm{Al}_{2} \mathrm{O}_{3}$ catalysts. Appl Catal A 2017; 529: 1-9.

Ramachandran R, Menon RK. An overview of industrial uses of hydrogen. Int J Hydrogen Energy 1998; 23: 593-598.

Saw W, McKinnon H, Gilmour I, Pang S. Production of hydrogen-rich syngas from steam gasification of blend of biosolids and wood using a dual fluidised bed gasifier. Fuel 2012; 93; 473-478.

Sepehri S, Rezaei M, Garbarino G, Busca G. Preparation and characterization of mesoporous nanocrystalline La-, Ce-, $\mathrm{Zr}$-, Sr-containing $\mathrm{NiAl}_{2} \mathrm{O}_{3}$ methane autothermal reforming catalysts. Int J Hydrogen Energy 2016; 41: 8855-8862.

Shelepova E, Vedyagin A, Sadykov V, Mezentseva N, Fedorova Y, Smorygo 0, Klenov O, Mishakov I. Theoretical and experimental study of methane partial oxidation to syngas in catalytic 
membrane reactor with asymmetric oxygen-permeable membrane. Catal Today 2016; 268: 103-110.

Shen Y, Lua AC. Polyol synthesis of nickel-copper based catalysts for hydrogen production by methane decomposition. Int J Hydrogen Energy 2015; 40: 311-321.

Shen Y, Lua AC. A trimodal porous carbon as an effective catalyst for hydrogen production by methane decomposition. J Colloid Interface Sci 2016; 462: 48-55.

Song S, Zhang P, Zhang X, Han M. Partial oxidation of methane reaction in $\mathrm{Ba}_{0.9} \mathrm{Co}_{0.7} \mathrm{Fe}_{0.2} \mathrm{Nb}_{0.1} \mathrm{O}_{3-\delta}$ oxygen permeation membrane with three-layer structure. Int J Hydrogen Energy 2015; 40: 10894-10901.

Starik A, Kuleshov P, Loukhovitski B, Titova N. Theoretical study of partial oxidation of methane by non-equilibrium oxygen plasma to produce hydrogen rich syngas. Int J Hydrogen Energy 2015; 40: 9872-9884.

Teo KB, Singh C, Chhowalla M, Milne WI. Catalytic synthesis of carbon nanotubes and nanofibers. In: Nalwa HS, editor. Encyclopedia of nanoscience and nanotechnology, Vol. 10. USA: American Scientific Publishers, 2003: 1-22.

Van Der Laan GP, Beenackers A. Kinetics and selectivity of the FischerTropsch synthesis: a literature review. Catal Rev 1999; 41: 255-318.

Velasco JA, Fernandez C, Lopez L, Cabrera S, Boutonnet M, Järås S. Catalytic partial oxidation of methane over nickel and ruthenium based catalysts under low $\mathrm{O}_{2} / \mathrm{CH}_{4}$ ratios and with addition of steam. Fuel 2015; 153: 192-201.

Wang Y, Liu T, Fang S, Xiao G, Wang H, Chen F. A novel clean and effective syngas production system based on partial oxidation of methane assisted solid oxide co-electrolysis process. I Power Sources 2015; 277: 261-267.

Wang Y, Wang S, Zhao G, Guo Y, Guo Y. Hydrogen production by partial oxidation gasification of a phenol, naphthalene, and acetic acid mixture in supercritical water. Int J Hydrogen Energy 2016; 41: 2238-2246.

Wu C-C, Leu H-J. Examining the trends of technological development in hydrogen energy using patent co-word map analysis. Int J Hydrogen Energy 2014; 39; 19262-19269.

Wu H, La Parola V, Pantaleo G, Puleo F, Venezia AM, Liotta LF. $\mathrm{Ni}$-based catalysts for low temperature methane steam reforming: recent results on $\mathrm{Ni}-\mathrm{Au}$ and comparison with other bi-metallic systems. Catalysts 2013; 3: 563-583.

Xu J, Su X, Liu X, Pan X, Pei G, Huang Y, Wang X, Zhang T, Geng $\mathrm{H}$. Methanol synthesis from $\mathrm{CO}_{2}$ and $\mathrm{H}_{2}$ over $\mathrm{Pd} / \mathrm{ZnO} / \mathrm{Al}_{2} \mathrm{O}_{3}$ : catalyst structure dependence of methanol selectivity. Appl Catal A 2016; 514: 51-59.

Yan Y, Zhang J, Zhang L. Properties of thermodynamic equilibrium-based methane autothermal reforming to generate hydrogen. Int J Hydrogen Energy 2013; 38: 15744-15750.

Yan Y, Zhang Z, Zhang L, Wang X, Liu K, Yang Z. Investigation of autothermal reforming of methane for hydrogen production in a spiral multi-cylinder micro-reactor used for mobile fuel cell. Int J Hydrogen Energy 2015; 40: 1886-1893.
Ying Y, Meisheng C, Minglai L, Na Z, Zhiqi L, Yongxi S. Rare earth modified Ni-Si catalysts for hydrogen production from methane decomposition. J Rare Earths 2014; 32: 709-714.

Zhu L, Li L, Fan J. A modified process for overcoming the drawbacks of conventional steam methane reforming for hydrogen production: thermodynamic investigation. Chem Eng Res Des 2015; 104: 792-806.

\section{Bionotes}

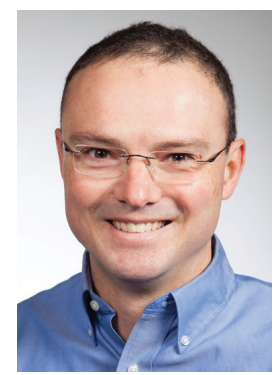

Matthew James Watson

Department of Chemical and Process Engineering, College of Engineering, University of Canterbury, Private Bag 4800, Christchurch 8140, New Zealand matthew.watson@canterbury.ac.nz

Matthew James Watson joined the Department of Chemical and Process Engineering, University of Canterbury in 2015 as an Associate Professor, after more than 15 years of applied R\&D experience at Air Products and Chemicals Inc., Pennsylvania. He earned his BE degree from the University of Canterbury in New Zealand and his MSc and PhD from Lehigh University, USA. His research interest includes developing and investigating novel materials such as structured catalyst and adsorbent supports, high-temperature electrolytic reduction of metals, new applications for oxy-fuel combustion and oxygen generation from waste heat.

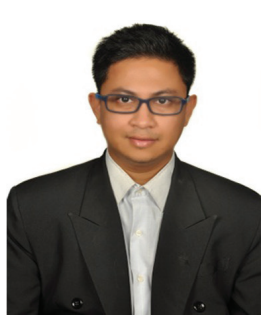

\section{Luqmanulhakim Baharudin}

Department of Chemical and Process Engineering, College of Engineering, University of Canterbury, Christchurch 8140 , New Zealand

Luqmanulhakim Baharudin joined the Department of Chemical and Process Engineering, University of Canterbury in May 2016 as a PhD candidate. He earned his MPhil in Advanced Chemical Engineering Practice from the University of Cambridge, UK. He has had approximately 10 years of significant international industrial experience in the petrochemical industry working for HaldorTopsoe, Petronas and ExxonMobil. He is currently developing a monolithic catalytic system for water gas shift and steam methane reforming reactions. 